\title{
Din Görevlilerinin Toplumsal Cinsiyet Rollerine İlişkin Tutumları: Çorum Örneği*
}

\section{Attitudes of Religious Officials towards Gender Roles: The Case of Çorum}

\author{
Nihayet Kübra KIRAZ \\ Doktora Öğrencisi, Hitit Üniversitesi Lisansüstü Eğitim Enstitüsü, Din Sosyolojisi \\ Ph.D. Candidate, Hitit University Graduate Education Institute, Sociology of Religion \\ Çorum / Turkey \\ erenkiraz24@hotmail.com \\ orcid.org/0000-0002-8480-5310 \\ Yakup ÇOŞTU \\ Prof. Dr., Hitit Üniversitesi, Illahiyat Fakültesi, Din Sosyolojisi Anabilim Dalı \\ Prof., Hitit University, Faculty of Theology, Department of Sociology of Religion \\ Çorum / Turkey \\ yakupcostu@hitit.edu.tr \\ orcid.org/0000-0002-5672-9226
}

\section{Makale Bilgisi / Article Information}

\author{
Makale Türü / Article Types \\ : Araştırma Makalesi / Research Article \\ Geliş Tarihi / Received \\ : 21 Eylül / September 2021 \\ Kabul Tarihi / Accepted \\ : 9 Aralık / December 2021 \\ Yayın Tarihi / Published \\ : 15 Aralık / December 2021 \\ Yayın Sezonu / Pub Date Season : Aralık / December \\ Cilt / Volume: 8 - Sayı / Issue: 2 - Sayfa / Pages: 457-489 \\ Atıf / Cite as \\ Kiraz, Nihayet Kübra - Çoștu, Yakup. “Din Görevlilerinin Toplumsal Cinsiyet Rollerine İlișkin Tutumları: Çorum Örneği”. \\ Bülent Ecevit Üniversitesi Illahiyat Fakültesi Dergisi 8/2 (2021), 457-489. \\ Doi: 10.33460/beuifd.998507 \\ İntihal / Plagiarism \\ Bu makale, en az iki hakem tarafından incelendi ve intihal içermediği teyit edildi. \\ This article has been reviewed by at least two referees and scanned via a plagiarism software. \\ Yayın Hakkı / Copyright ${ }^{\circ}$ \\ CC BY-NC-ND 4.0 | Zonguldak Bülent Ecevit Üniversitesi, İlahiyat Fakültesi tarafından yayınlanmıştır. Telif ve yayın \\ hakları, Creative Commons Atıf-Gayri Ticari-Türetilemez 4.0 lisansının hüküm ve koşullarına tabidir. \\ CC BY-NC-ND 4.0 Published by Zonguldak Bulent Ecevit University. Copyrights are subjected to the terms and conditions \\ of a Creative Commons Attribution-NonCommercial-No Derivatives License 4.0.
}

Öz: Toplumsal cinsiyet, toplumsal olarak belirlenen kadın ve erkek rollerini, sorumluluklarını ifade eden bir kavramdır. Toplumun yapısı, dini algılayış, zaman, etnik yapı, aile yapısı gibi faktörler toplumsal cinsiyet rollerini şekillendirmektedir. Bu makale din ve toplumsal cinsiyet ilişkisini, din görevlilerinin toplumsal cinsiyet rollerine ilişkin algıları üzerinden araştırmayı hedeflemektedir. Araştırma, Çorum II Müftülüğüne bağlı il merkezi ve merkeze bağlı köylerde görev yapan 527 din görevlisini kapsamaktadır. Araştırmanın

* Bu makale, aynı isimle tamamlanan (Hitit Üniversitesi, Lisansüstü Eğitim Enstitüsü, Felsefe ve Din Bilimleri Anabilim Dalı, 2021) yüksek lisans tezinden üretilmiştir. 
verileri, din görevlilerinin sosyo-demografik özelliklerini belirlemeye yönelik anket formu, geçerlik ve güvenirliği 2008 yılında Zeyneloğlu tarafından ortaya konulan 'Toplumsal Cinsiyet Rolleri Tutum Ölçeği' kullanılarak elde edilmiştir. Veriler değerlendirilirken iki örneklemin ortalamalarının karşılaştırılmasında Bağımsız Örneklem t-testi, ikiden çok örneklemin ortalamalarının karşılaştırılmasında Tek Yönlü Anova Testi ve çoklu karşılaştırmalar için ise Tukey HSD testi ve tanımlayıcı istatistikler kullanılmıştır. Araştırmada din görevlilerinin Toplumsal Cinsiyet Rolleri Tutum Ölçeği toplam puan ortalamasının $129,92 \pm 12,18$ olduğu belirlenmiştir. Elde edilen bu sonuç toplumsal cinsiyet rolleri karşııında din görevlilerinin eşitlikçi bir tavır içinde olduklarını göstermektedir. Bunun yanı sıra, elde edilen verilere göre, din görevlilerinin yaş, cinsiyet, eğitim durumu, eşin eğitim durumu, görev türü, görev yeri ve hizmet yılı gibi değişkenlere göre toplumsal cinsiyet rollerine ilişkin tutumlarında farklılıklar tespit edilmiştir.

Anahtar Kelimeler: Din Sosyolojisi, Toplumsal Cinsiyet, Din Görevlisi, Kadın, Çorum.

\begin{abstract}
Gender is a concept that expresses the socially determined roles and responsibilities of men and women. Factors such as the structure of society, religious perception, time, ethnicity and family structure, shape gender roles. This article aims to investigate the relationship between religion and gender through religious officials' perceptions of gender roles. The research includes 527 religious officials working in the provincial centre and villages of the Çorum Provincial office of Mufti. The research data was obtained by the questionnaire form for determining the socio-demographic characteristics of religious officials, the 'Gender Roles Attitude Scale', the validity and reliability of which was revealed by Zeyneloglu in 2008. While evaluating the data, the Independent Samples T-Test was used to compare the means of two samples, the One Way ANOVA Test to compare the means of more than two samples and the Tukey HSD test and descriptive statistics were used for multiple comparisons. In the study, it was determined that the total point average of the Gender Roles Attitude Scale of religious officials was $129.92 \pm 12.18$. This result indicates that religious officials have an egalitarian attitude towards gender roles. Differences in attitudes towards gender roles were determined according to variables such as education level, spouse's education level, job type, place of work and years of service.
\end{abstract}

Keywords: Sociology of Religion, Gender, Religious Official, Woman, Çorum.

\title{
Giriş
}

Biyolojik olarak kadın veya erkek olma anlamına gelen cinsiyet (sex), temelde basit ve ayrımcılık içermeyen bir durumken ${ }^{1}$ zamanla derin farklılıklarla tartışılan bir konuya dönüşmüştür. Bu farklılıklar, toplumsal olarak belirlenen kadın ve erkek rollerini ifade eden toplumsal cinsiyet (gender) ${ }^{2}$ konusu üzerinden ele alınmaktadır.

1 Zehra Yaşın Dökmen, Toplumsal Cinsiyet Sosyal Psikolojik Açıklamalar (İstanbul: Remzi Kitabevi, 2019$), 19$.

2 World Health Organisation (WHO), "Gender and Health", Tecnical Paper, (Switzerland), 56. 
Toplumsal cinsiyeti, biyolojik cinsiyetten ayıran en belirleyici özellik onun sosyo-kültürel ortamda belirlenmesi ve buna bağlı olarak toplumdan topluma değişen bir konumda olmasıdır. ${ }^{3}$ Toplumun cinsiyete dayalı olarak kadın ve erkeğe yüklediği rolleri ve beklentileri içeren toplumsal cinsiyet, kız ya da erkek cinsiyetiyle dünyaya gelen bireylerin toplumsal inşa ile kadınlaşma ve erkekleşmeleri sürecidir. Daha doğumdan itibaren kız bebekler için pembe, erkek bebekler için mavi rengin tercih edilmesiyle başlayan bu süreç farklı kültürel ve siyasi zeminlerde farklı söylemler şeklinde biçimlenir. ${ }^{5}$ Yani her toplumun cinsiyete/cinsiyetler arası ilişkilere bakışı kendine özgüdür. Toplumun sosyo-kültürel yapısı, aile, okul, arkadaş çevresi, medya vb. kurumlar aracılığıyla toplumsal cinsiyet algısı tekrar tekrar üretilmekte ve bu durum mevcut yapıyı beslemektedir. ${ }^{6}$ Bu anlamda din de toplumsal cinsiyet çözümlemelerinde etkili bir faktör olarak değerlendirilmektedir.

Bu çalışma, genel anlamda din-toplumsal cinsiyet, özelde ise İslamiyet-toplumsal cinsiyet ilişkisini ele almaktadır. Bu bağlamda "Dinî eğitim almış ve dini öğretmeyi/ibadetlerin usulüne uygun şekilde yapılmasına rehberlik etmeyi meslek edinmiş kişiler olarak din görevlilerinin toplumsal cinsiyet rollerine ilişkin tutumları nasıldır?" sorusu araştırmanın temel problemini oluşturmaktadır. Araştırmanın alt problemleri olarak şu soruların cevapları araştırılmıştır:

1. Din görevlilerinin cinsiyetleri, onların toplumsal cinsiyet rollerine ilişkin tutumlarını farklılaştırmış mıdır?

2. Din görevlilerinin yaşları onların toplumsal cinsiyet rollerine ilişkin tutumlarını etkilemiş midir?

3. Din görevlilerinin ve eşlerinin eğitim seviyeleri onların toplumsal cinsiyet rollerine ilişkin tutumlarını etkilemiş midir?

4. Din görevlilerinin görev yerleri ve görevde hizmet süreleri onların toplumsal cinsiyet rollerine ilişkin tutumlarını etkilemiş midir?

Yapılan literatür taramalarında din ile toplumsal cinsiyet ilişkisine yönelik pek çok çalışma yapıldığı tespit edilmiştir: Gülşah Tam "Diyanet Çalışanlarının Toplumsal Cinsiyet Rollerine İlişkin Tutumları" isimli çalışmasında Mersin'in Yenişehir ilçesindeki diyanet çalışanlarının toplumsal cinsiyet rollerine ilişkin tutumlarını, Simge Zeyneloğlu, "Ankara'da Hemşirelik Öğrenimi Gören Üniversite Öğrencilerinin Toplumsal Cinsiyet Rollerine Illişkin Tutumları" isimli çalışmasında hemşirelik

\footnotetext{
3 Fatmagül Berktay, Tek Tanrılı Dinler Karşısında Kadın (İstanbul: Metis Yayınları, 2009), 16.

Asım Yapıcı, Toplumsal Cinsiyet Din ve Kadın (İstanbul: Çamlıca Yayınları, 2016), 23.

Judith Butler, Cinsiyet Belası, çev. Başak Ertür (Metis Yayınları, 2014), 46.

Robert William Connell, Toplumsal Cinsiyet ve iktidar (Istanbul: Ayrıntı Yayınları, 1998), 79.

Gülşah Tam, Diyanet Çalışanlarının Toplumsal Cinsiyet Rollerine Illişkin Tutumları (Mersin: Mersin Üniversitesi, Yüksek Lisans Tezi, 2020), 30.
} 
öğrenimi gören öğrencilerin toplumsal cinsiyeti rol tavırlarını, ${ }^{8}$ Eda Ünalan "Türkiye'deki Üniversite Kütüphanelerinde Çalışan Kütüphanecilerin Toplumsal Cinsiyet Algısı" isimli çalışmasında kütüphanecilerin toplumsal cinsiyet algısını araştırmıştır. ${ }^{9}$ Harun Tunç, "Toplumsal Değişim Sürecinde Din ve Toplumsal Cinsiyet" isimli çalışmada lise gençliğinin ${ }^{10}$, Fatma Keskin, "Ilahiyat Fakültesi Öğrencilerinin Toplumsal Cinsiyet Rollerine İlişkin Tutumlar" isimli çalışmasında ilahiyat fakültesi öğrencilerinin toplumsal cinsiyet rollerine ilişkin tutumlarını değerlendirmiştir. ${ }^{11}$ Sümeyra Ünalan Turan ve Vejdi Bilgin, "Toplumsal Cinsiyet Ekseninde Din ve Aile İçi Roller" isimli çalışmada, yükseköğrenim görmüş çalışan dindar kadınlar ve eşlerini; aile içi sorumluluk paylaşımı konusunu ele almışlardır. ${ }^{12}$ Ayşe Çağrıcı Zengin, "Dindarlık ve Toplumsal Cinsiyet Ayrımcılığı" isimli çalışmasında dindarlığın toplumsal cinsiyet ayrımcılığına yol açıp açmadığını araştırmıştır. ${ }^{13}$ Emine Öztürk, "Türkiye'de Aile İçi Şiddet Kadın Sığınma Evleri ve Din" isimli çalışmasında, konuyu kadın sığınma evleri ve din çerçevesinde değerlendirmiştir. ${ }^{14}$ İhsan Toker, "Bir Yapılaşma Iliş̧kisi Olarak Kadınlar ve Din -Başkent Kadın Platformu Örnek Olayı-"isimli çalışmasında din ve kadın ilişkisini inanç, pratikler ve sosyal bakımdan ele almıştır. ${ }^{15}$ Mustafa Tekin, "Türkiye `de Aydın Kadınlara Göre Din ve Kadın" isimli çalışmasında, din ve kadın sorunsalını aydın kadınların gözünden değerlendirmiştir. ${ }^{16}$ İhsan Toker, "Dinler Ataerkil Yapılar Mıdır? Bir Çifte İmkanlılık Konusu Olarak Din ve Kadın" isimli çalışmasında din ve kadın ilişkisinin çok yönlülüğü üzerinde durmuştur. ${ }^{17}$ Yıldız Kuzgun ve Seher A. Sevim, "Kadınların Çalışmasına Karşı Tutum ve Dini Yönelim Arasındaki Iliş̧ki" isimli çalışmalarında toplumsal cinsiyet ve din ilişkisini dinî yönelim ile kadının çalışmasına karşı tutum bağlamında ele almışlardır. ${ }^{18}$ Asım Yapıcı, "Yeni Bir Dindarlık Ölçeği ve Üniversiteli Gençlerin Dinin Etkisini Hissetme Düzeyi: Çukurova Üniversitesi Örneği" isimli çalışmasında hazırladığı dinin etkisini hissetme ölçeğinde toplumsal cinsiyet algısı ile ilgili

8 Simge Zeyneloğlu, Ankara'da Hemşirelik Öğrenimi Gören Üniversite Öğrencilerinin Toplumsal Cinsiyet Rollerine Illişkin Tutumları (Ankara: Hacettepe Üniversitesi, Doktora Tezi, 2008).

9 Eda Ünalan, Türkiye'deki Üniversite Kütüphanelerinde Çalışan Kütüphanecilerin Toplumsal Cinsiyet Algısı (Ankara: Ankara Üniversitesi, Yüksek Lisans Tezi, 2020).

10 Harun Tunç, Toplumsal Değişim Sürecinde Din ve Toplumsal Cinsiyet (Kahramanmaraş: Kahramanmaraş Sütçü İmam Üniversitesi, Yüksek Lisans Tezi, 2013).

11 Fatma Keskin, Illahiyat Fakültesi Öğrencilerinin Toplumsal Cinsiyet Rollerine Iliş̧kin Tutumları (Konya: Necmettin Erbakan Üniversitesi, Yüksek Lisans Tezi, 2019).

12 Ünalan Turan, Sümeyra, Bilgin, Vejdi, "Toplumsal Cinsiyet Ekseninde Din ve Aile İçi Roller”, Uludağ Üniversitesi ilahiyat Fakültesi Dergisi, 29/2 (Aralık 2020), 459-493.

13 Ayşe Çağrıcı Zengin, Dindarlık ve Toplumsal Cinsiyet Ayrımcılı̆ıı (Sivas: Cumhuriyet Üniversitesi, Doktora Tezi, 2019).

14 Emine Öztürk, Türkiye'de Aile lçi Şiddet Kadın Sığınma Evleri ve Din (İstanbul: Marmara Üniversitesi, Doktora Tezi, 2008).

15 İhsan Toker, Bir Yapılaşma Iliş̧kisi Olarak Kadınlar ve Din -Başkent Kadın Platformu Örnek Olayı- (Ankara: Ankara Üniversitesi, Doktora Tezi, 2005).

16 Mustafa Tekin, Türkiye` de Aydın Kadınlara Göre Din ve Kadın (Konya: Selçuk Üniversitesi, Doktora Tezi, 2003).

17 İhsan Toker, "Dinler Ataerkil Yapılar Mıdır? Bir Çifte İmkanlılık Konusu Olarak Din ve Kadın”, Eski Yeni 12 (2009), 15-21.

18 Yıldız Kuzgun - Seher A. Sevim, "Kadınların Çalışmasına Karşı Tutum ve Dini Yönelim Arasındaki Illişki", Ankara Üniversitesi Eğitim Bilimleri Fakültesi Dergisi 37/1 (2004), 14-27. 
maddelere de yer vererek dinin kadın erkek ilişkilerindeki etkisine değinmiştir. ${ }^{19}$ Veysel Uysal, “Günümüz Türk Toplumunda Dinsellik ve Kadın/Erkek Aleyhtarı Tutumlar" isimli çalışmasında kadın erkek aleyhtarlığının dinsellikle ilişkisini araştırmıştır. ${ }^{20}$ Birsen Banu Okutan, "Akışkan Modern Zamanlarda Kadın ve Din: Yaşama Üslubundan Hayat Tarzına Habitusun Değişimi" adlı çalışmasında akışkan modern zamanların dini habitusu nasıl etkilediğini ele almıştır. ${ }^{21}$ Görüldüğü gibi bu çalışmalar farklı yaş, cinsiyet ve meslek gruplarının toplumsal cinsiyet algılarını, kadın ve din ilişkisini yansıtmaktadır. Bu doğrultuda özel olarak din görevlilerinin toplumsal cinsiyet rollerine ilişkin tutumlarına yönelik çalışmaların yetersiz olduğu görülmektedir. Dolayısıyla bu alanda yapılacak çalışmaların artmasının, daha kapsamlı değerlendirmelere katkı sağlayacağı ve yaptığımız çalışmanın da literatürü zenginleştireceği düşünülmektedir.

Yaptığımız çalışmada Çorum İ Müftülüğüne bağlı merkez ve merkeze bağlı köylerde çalışan din görevlilerinin toplumsal cinsiyet rol tutumlarıyla ilişkisi, nicel teknikle ele alınıp tartışılmıştır.

\section{Cinsiyet, Toplumsal Cinsiyet ve Toplumsal Cinsiyet Rolleri}

Insanları sınıflandırmanın en yaygın kriterlerinden biri de cinsiyettir. Cinsiyet, biyolojik olarak kadın ve erkek olmayı ifade etmenin yanı sıra, bireyi biyolojik cinsiyete dayalı olarak belirleyen demografik bir kategoridir. Kadın ve erkeğin kromozom sayıları, üreme fonksiyonundaki ve hormonal farklılıkları cinsiyete dayalı olarak değişir. ${ }^{22}$ Türkçe Sözlük, cinsiyeti "erkekle dişiyi ayırt ettiren yaradılış özelliği, eşey, cinslik, seks"23 olarak tanımlar.

Toplumsal cinsiyet, kadın ve erkeklere uygun görülen rollerin toplum tarafından inşa edildiğini ifade eder, dolayısıyla bu konudaki biyolojik izahları reddeder. ${ }^{24}$ Böylelikle toplumda kadını dezavantajlı hale getiren düzenlemelerin de önüne geçmeyi hedefler. ${ }^{25}$ Buna göre kadınların ve erkeklerin toplumda farklı algılanışının nedeni biyolojik farklılıklar değil, toplumun örgütlenme biçimidir. Cinslerin nasıl düşünmesi ve nasıl hareket etmesi gerektiği toplum tarafından belirlenir. ${ }^{26}$ Bhasin'e göre toplumsal cinsiyet toplumun kadını ve erkeği birbirinden

19 Asım Yapıcı, "Yeni Bir Dindarlık Ölçeği ve Üniversiteli Gençlerin Dinin Etkisini Hissetme Düzeyi: Çukurova Üniversitesi Örneği", Çukurova Üniversitesi Illahiyat Fakültesi Dergisi 6/1 (2006), 65-115.

20 Veysel Uysal, "Günümüz Türk Toplumunda Dinsellik ve Kadın/Erkek Aleyhtarı Tutumlar”, Marmara Üniversitesi Illahiyat Fakültesi Dergisi 20 (2001), 81-114.

21 Birsen Banu Okutan, "Akışkan Modern Zamanlarda Kadın ve Din: Yaşama Üslubundan Hayat Tarzına Habitusun Değişimi", Dini Araştırmalar 19/49 (2016), 229-253.

22 Dökmen, Toplumsal Cinsiyet Sosyal Psikolojik Açıklamalar, 19-24; Vivien Burr, Gender and Social Psychology (London and New York: Routledge, 1998), 11.

23 Komisyon, Örnekleriyle Türkçe Sözlük (İstanbul: MEB, 2000), "cinsiyet", 464.

24 Joan W. Scott, "Toplumsal Cinsiyet: Faydali Bir Tarihsel Analiz Kategorisi", çev. Derya Demirler - Fahriye Dinçer, Kültür ve Siyasette Feminist Yaklaşımlar 12 (2010), 116.

25 Mehmet Tayfun Amman, "Toplumsal Boyutlarıyla Cinsiyet- Sosyal, Bilimsel Yaklaşımlar-", Din ve Toplumsal Boyutlarıyla Cinsiyet Tartışmalı ilml ihtisas Toplantı, (2011), 16.

26 World Health Organisation (WHO), "Gender and Health", 56. 
ayırma biçimidir. Cinsiyet, cinsel organa göre belirlenirken toplumsal cinsiyet, toplumun kadına ve erkeğe uygun gördüğü roller üzerinden şekillenir. Bu roller kız ya da erkek olarak dünyaya gelen bireylere sosyo-kültürel ortamda paket halinde yüklenir/öğretilir/benimsetilir. Cinsiyet doğal, biyolojik, türe özgü ve değiştirilemez iken toplumsal cinsiyet tarihsel ve kültürel olarak inşa edilen değişken bir sürece karşılık gelmektedir. ${ }^{27}$ Bu süreç toplumun yapısına, dinin algılanışına, zamana, etnik yapıya, aileye göre farklılıklar gösterir. Sonuçta her toplumda kadının ve erkeğin toplumsal yaşama katılım ve toplumsal alanda temsillerine dair algılar oluşur. ${ }^{28}$ Toplumsal cinsiyet terimi, her ne kadar kadın ve erkek arasındaki farkın toplumsal inşasına vurgu yapsa da zamanla sembolik bir anlam kazanmış ve bu anlam toplumsal kurumlardaki cinsiyete dayalı iş bölümünü de kapsamaya başlamıştır. ${ }^{29}$

Toplumun kadınlara ve erkeklere biçtiği roller, toplumsal cinsiyet rolleri olarak ifade edilir. Bu roller cinsiyet kalıp yargılarını veya toplumun belirlediği cinsiyet farklılıklarını yansıtır. ${ }^{30}$ Cinsiyete ait farklılıklar daha doğumdan itibaren kız ya da erkek bebeklerin giydirilişi, kıyafetlerinde seçilen renkler, oyuncak seçimi, ya da hitap şekillerinde kendini göstermeye başlar. ${ }^{31}$ Her toplumun kadın ve erkek için tanımladığı ve davranışa dönüşmesini talep ettiği cinsiyet rolleri vardır. ${ }^{32}$ Bu roller bebeğin doğumundan itibaren başlayan bir sosyalleşme sürecinde öğrenilir. Süreç içinde kendi biyolojik cinsiyetine uygun rolleri öğrenen birey bunları içselleştirerek erkek veya dişi kimliğini benimsemiş olur. ${ }^{33}$ Evrensel biyolojik özelliklere göre oluşan cinsiyet rolü kategorileri, bireyin topluma katılma imkân ve tarzını belirlemede ve toplumda iş bölümünün oluşumuna zemin hazırlamada önemli bir etkendir. ${ }^{34}$

\section{Toplumsal Cinsiyet ve Din}

Toplumun kültürel yapısı, normlar, aile, eğitim, kitle iletişim araçları, arkadaş çevresi gibi pek çok etken, toplumsal cinsiyet algısının farklılaşmasına neden olabilmektedir. Bu etkenlerden biri de toplumun sosyo-kültürel yapılanmasında önemli bir rol oynayan "din"dir. Dinin toplumsal cinsiyet ile ilişkisine bakıldığında erkeklik ve din konusunda fazla çalışma yapılmadığı, ${ }^{35}$ konunun daha çok kadın ve din üzerine yoğunlaştığı görülmektedir. ${ }^{36}$

27 Kamla Bhasin, Toplumsal Cinsiyet: Bize Yüklenen Roller, çev. Kader Ay (İstanbul: Kadav Yayınları, 2003), 7-9.

28 Yapıcı, Toplumsal Cinsiyet Din ve Kadın, 24.

29 Gordon Marshall, Sosyoloji Sözlüğü, çev. Osman Akınhay ve Derya Kömürcü (Ankara: Bilim ve Sanat Yayınları, 1999), 98

30 Dökmen, Toplumsal Cinsiyet Sosyal Psikolojik Açıklamalar, 29.

31 Feryal Saygılıgil, Toplumsal Cinsiyet Tartışmaları (İstanbul: İstanbul Üniversitesi Açık ve Uzaktan Eğitim Fakültesi, 2010), 7.

32 Yapıcı, Toplumsal Cinsiyet Din ve Kadın, 30.

33 Anthony Giddens, Sosyoloji, çev. İsmail Yılmaz (İstanbul: Kırmızı Yayınları, 2012 ), 526.

34 Selmin Evrim, Şahsiyet Alanında Rol Sorununa Giriş (İstanbul: İstanbul Üniversitesi Edebiyat Fakültesi Yayınları, 1972), 102.

35 Birsen Banu Okutan, Erillik ve Din: İslamcı Habitus Sorgulanıyor (İstanbul: Rağbet Yayınları, 2017), 42.

36 Birsen Banu Okutan, “Din ve Toplumsal Cinsiyet Çalışmalarının Teorik ve Metodolojik İmkânı: Literatürel Bir Değerlendirme", Toplum Bilimleri Dergisi 7/13 (2013), 10. 
Din ve kadın ilişkisi tek taraflı, değiş̧mez ve statik bir ilişki değildir. Dini metinlerde kadınların rolleri, erkekler karşısındaki konumları ele alınırken eşitlik, tamamlayıcılık ve melezlik gibi farklı boyutlar öne çıkmaktadır. ${ }^{37}$ Bu bağlamda dinlerin toplumsal cinsiyet açısından en çok öne çıkan görünümü, ataerkillikle ilişskilendirilmesidir. ${ }^{38}$ Dinlerin ataerkilliği görüşü; dinlerin baba figür tarafından yönetilmeleri, dünyadaki belli başlı dinlerin kurucularının erkek olması, dinlerde hâkim rollerin erkeklere verilmesi, dinlerin çoğunun erkek liderlerin bulunduğu toplumsal düzende tezahür etmesine dayandırılmaktadır. ${ }^{39} \mathrm{Bu}$ görüş dinlerin, kadınlara baskı uyguladığını, kadınları zayıflatarak erkeklere boyun eğmelerine meşruluk kazandırdığını iddia etmektedir. ${ }^{40}$ Buna göre dinlerin ortak bir özelliği, kadına karşı olumsuz bir tutum içinde olmalarıdır. Önce erkekler/ sadece erkekler türünden bir modellemenin tüm dünya dinlerinde ortak olduğu düşünülür. ${ }^{41}$

Dinin toplumsal işlevlerinden biri meşrulaştırmadır. Bireyler ve toplumlar hatta devletler dinin meşrulaştırıcı işlevi sayesinde yaptıklarına haklılık/geçerlilik kazandırır. ${ }^{42}$ Bu bağlamda din adına ortaya konan uygulamalar kadının erkek karşısında ikincil konumda kalmasına neden olmakta hem aile içi eşitliğin sağlanmasını hem de kadınların durumunu iyileştirecek yeniden yapılanmaları engelleyebilmektedir. Böylece dinsel yorumlama tarzı, hakların inkârı için gerekçe olabilmektedir. ${ }^{43}$

İslamiyet ve kadın meselesiyle ilgili tartışmalar temelde üç farklı görüş etrafında şekillenmektedir. Bu görüşlerden ilki seküler bir bakış açısıyla İslam'ın (Kur'an'ın, Hz. Peygamber'in) kadına değer vermeyip onu erkek karşısında aşağı bir konuma yerleştirdiğini iddia eder. İkinci görüş ise meseleyi dinî bir çerçevede ele alıp İslam'ın kadını yücelttiğini, tanıdığı hak ve hürriyetlerle kadını erkekten aşağıda konumlandırmadığını savunmaktadır. Burada dikkat çeken bir husus her iki tarafın da Kur'an ayetlerinden ve sünnetten yola çıkarak haklılıklarını ispatlamaya çalışmaları, hatta kimi zaman aynı ayet ve hadisleri dayanak göstermeleridir. ${ }^{44}$ Bu tartışmaların yanı sıra üçüncü görüş de referanslarını dinden almakla beraber Kur'an'ın ve hadislerin kadın bakış açısıyla ve yeni metotlarla yorumlanması gerektiğini savunanlara aittir. Yazarının din ve dünyayı algılama biçimine göre farklılık gösteren bu yaklaşımlardan ${ }^{45}$ ilki, moderniteyi sorgusuzca kabul

37 İhsan Toker, "Eşitlik ve Adalet Kavramları Çerçevesinde Müslüman Kadınlarda Toplumsal Cinsiyet Örüntüleri", Ankara Üniversitesi Sosyal Bilimler Enstitüsü Dergisi 1/1 (2009), 142.

38 Hesna Serra Aksel, "Feminist Perspektiften Yahudilik: Bir Yeniden İnşa Girişimi”, Hitit Ilahiyat Dergisi 20/1 (2021), 148-149.

39 Mary Pat Fisher, Women in Religion (New York: Pearson \& Longman, 2007), 13.

40 İhsan Toker, "Toplumsal Cinsiyet ve Din”, Din Sosyolojisi, ed. Niyazi Akyüz - Ihsan Çapcıoğlu (Ankara: Grafiker Yayınları, 2018), 609.

41 Ronald L. Johnstone, Religion on Society: Sociology of Religion (Prentice Hall, 2006), 228.

42 Nazife Gürhan, “Toplumsal Cinsiyet ve Din", e-Şarkiyat Ilmi Araştırmalar Dergisi 4 (Kasım 2010), 62.

43 Fatmagül Berktay, Tarihin Cinsiyeti (İstanbul: Metis Yayınları, 2018), 63-64.

44 Hayri Kırbaşoğlu, “Kadın Konusunda Kur'ân'a Yöneltilen Başlıca Eleştiriler”, İslamî Araştırmalar 10/4 (1997), 259.

45 Yapıcı, Toplumsal Cinsiyet Din ve Kadın, 17-19. 
eden oryantalist bir tavır içindedir. İkincisi, oryantalistlere karşı Müslümanlığı özü itibariyle savunur. Üçüncü görüş ise hem Batıdan etkilenmekte hem de onu eleştirmektedir. Fakat bu grubun etkilenme seviyeleri eleştiri seviyelerinden daha baskın görünmektedir. ${ }^{46}$

Literatür taramalarında İslamiyet'in kadını ikincilleștirdiğini savunanların dinle bir hesaplaşma çabasında oldukları, yorumlarını ekonomik, siyasi, sosyal ya da coğrafi bağlamdan bağımsız olarak gerçekleştirdikleri görülmektedir. ${ }^{47} \mathrm{Bu}$ grup eleştirilerini genellikle şu konular üstünde yoğunlaştırmıştır: Ailede otoritenin erkeğe verilmesi, bazı ayet ve hadis metinlerinde kadın aleyhine değerlendirilen ifadelerin yer alması, kadının birey oluşunun hoş karşılanmaması, ${ }^{48}$ erkeklerin kadınlar üzerinde kavvam (hüküm sahibi) olması, mirasta kız ve erkek çocuk arasındaki eşitsiz paylaşım, şahitlik konusunda kadın ve erkek arasındaki eşitsizlik, kadına eşini boşama hakkı verilmemesi, kadının örtünmesi, erkeğin dört evlilik yapmasına izin verilmesi, gibi. ${ }^{49}$

Tek tanılı dinlerin kadının statüsü üzerine etkilerini karşılaştırmalı bir şekilde ele alan Berktay, İslamiyet'in kadını birey olarak görmediğini, kadının erkek için var olduğunu söyler. ${ }^{50}$ İslamiyet'in sunduğu total yaşam tarzı, Tanrı ile insan arasında kalmaz; özellikle aileye, evlenmeye, boşanmaya, mirasa dair düzenlemeler yapar. Kadına ikincil roller verir. İslam'ın bu bütüncül yapısı toplumun tüm kurumlarına dinî bir görünüm verir. İslamiyet'in gelişiyle kadınların durumunun iyileştiği fikrine katılmayan Berktay, sanılanın aksine İslam'dan önce de belli bir kadın sınıfının sosyal statü yönünden daha iyi durumda olduğunu söyler. ${ }^{51}$

Nilüfer Göle, İslam ve kadın ilişkisini örtünmeküzerinden değerlendirir. Kadının örtünmesini bir çeşit cinsiyet ayrımı olarak değerlendiren Göle, örtünen kadının erkeğin görsel ayrıcalığını açık ettiğini söyler. Göle'ye göre özellikle kadınlar, İslamî kimliklerini vurgulamak suretiyle Batı karşısında var olabilme çabasına girerler. Onlar için İslam, modernizmle başa çıkmanın bir aracı olmaktadır. Her ne kadar İslamcı kadınlar kamusal alanda görünürlük kazansa da kendi mahrem alanları içinde İslamî kurallara karşı gelerek kadın erkek ilişkilerinde yıkım oluşturmaktadır. ${ }^{52}$

Konuyu oryantalist bakış açısıyla değerlendiren Mernissi de gelenekle hesaplaşma eğilimindeki yazarlardan biridir. ${ }^{53}$ Mernissi, İslam'ın dünyevi (mekânsal) boyutu üzerinde durur. Ona göre İslam, cinsel mekânın sınırlarını belirlemek

46 Yapıcı, Toplumsal Cinsiyet Din ve Kadın, 91-92.

47 H. Şule Albayrak, “Kadın Olmak \& İslam, Gelenek, Modernlik ve Ötesi” (İstanbul: İz Yayıncılık, 2019), 20.

48 Toker, "Toplumsal Cinsiyet ve Din", 611.

49 Hülya Terzioğlu, "Toplumsal Cinsiyet Anlayışına Katkıı Bağlamında Dini Söylemin Etkisi", Kelam Araştırmaları Dergisi 14/2 (2016), 542.

50 Berktay, Tek Tanrılı Dinler Karşııında Kadın, 66.

51 Berktay, Tek Tanrılı Dinler Karşısında Kadın, 108-125.

52 Nilüfer Göle, Modern Mahrem (İstanbul: Metis Yayınları, 1991), 135-139.

53 Yapıcı, Toplumsal Cinsiyet Din ve Kadın, 17. 
suretiyle kadın erkek arasında bir hiyerarşi oluşturur. ${ }^{54}$ Mernissi, kadının erkekten aşağı olma nedenini biyolojik veya ideolojik kuramlarla açıklamaz. Ona göre İslam'ın kurumsal araçları (aile, çokeşlilik, boşanma, cinsel ayrım gibi), kadının erkeğe itaatini zorunlu kılarak onun gücünü zayıflatır. Kadın, gücünü cinsiyetinden alan bir fitnedir. Denetim altında tutulması gerekir. ${ }^{55}$

Aynur'a göre Mernissi'nin İslamiyet ve kadınla ilgili yaptığı değerlendirmeler Kur'an'ın ilgili ayetiyle doğrudan bağlantı kurulmadan belli bir metot takip edilmeden yapılmıştır. Yaptığı tespitler Kur'an'dan çok 'İslamî hafıza' olarak adlandırdığı tarihsel sürece odaklanır. Yani onun eleştirileri Kur'an ve İslamiyet'ten ziyade gelenekteki Müslüman toplumların deneyimleri ile ilgilidir. ${ }^{56}$

İslam'ın kadına değer verdiğini savunanlar, Aynur gibi İslam’ı ve Kur'an'ı eleştirenlerin hem taraflı oldukları hem de Kur'an'ı yorumlamada bazı metodik hatalara düştükleri kanaatindedirler. Bu hatalar genel hatlarıyla şunlardır: Konuyla ilgili ayetlerin bütüncül değil, parçacı bir yaklaşımla değerlendirilmesi, ayetlerin sadece zahiri anlamlarıyla ele alınması, ayetlerin indirilme nedenlerinin ve indirildiği dönemin tarihsel ve sosyal şartlarının dikkate alınmaması, Müslümanların bütün uygulamalarının Kur'an'ın emri gibi gösterilmeye çalışılmasıdır. ${ }^{77}$ İslamiyet'in kadını aşağıladığına delil olarak gösterilen ve hadis olduğu öne sürülen ifadeler ise Kur'an'daki ifadelerle çeliştiğine göre sahih olması mümkün değildir. Bunlar Müslüman toplumların İslamiyet'ten önceki kültürel alışkanlıklarının bir uzantısıdır. ${ }^{58}$

Kadının hak ettiği değeri İslamiyet sayesinde elde ettiğini savunan Çaviş, her türlü eşitsizlik, saldırı ve zorbalık karşısında kadının en büyük dayanağının Kur'an olduğu görüşündedir. İslam'a göre kadın ve erkek yükümlülükte, emirde, nehiyde, uyarmada ve müjdelemede birdir. Allah kendisi ile erkek kulları arasına perde koymadığı gibi kadın kullarıyla arasına da perde koymamıştır. Havva, Meryem, Asiye, Sare, Hz. Peygamberin eşleri, kızı Fatıma gibi birçok kadın, Allah'ın safi kulları olarak tanınmıştır. ${ }^{59}$

Çaviş, İslam'ın kadına bakışında eleştiri sebebi olan miras ve şahitlik meselelerini savunmacı açıklamalarla izah eder: İslam erkeğe kadının iki katı miras hakkı tanımadan önce, hem erkeğe nafaka ve barınma gibi sorumluluklar yüklemiş, hem de kadın yararına pek çok hukukî düzenlemeler yapmıştır. Bu durum kadının mağduriyetini engellemektedir. Şahitlik konusunda ise iki kadının şahitliğinin bir erkeğinkine denk olması, kayıtsız şartsız her durum için geçerli olmayıp bazı konularla sınırlandırılmıştır. Şahitlikteki bu ayrım, kadınların olaylardan çabuk et-

54 Fatıma Mernissi, Peçenin Ötesi, çev. Mine Küpçü (İstanbul: Yayınevi Yayıncılık, 1995), 15-16.

55 Mernissi, Peçenin Ötesi, 44-74.

56 Hatice Şahin Aynur, "İslamî Feminizm ve Feminist Kur'ân Okumaları Üzerine Genel Bir Değerlendirme”, Dinbilimleri Akademik Araştırma Dergisi 13/1 (2013), 101-102.

57 Kırbaşoğlu, “Kadın Konusunda Kur'ân’a Yöneltilen Başlıca Eleştiriler”, 270.

58 Salih Akdemir, "Tarih Boyunca ve Kur'an-ı Kerim'de Kadın”, İslamî Araştırmalar 10/4 (1997), 250.

59 Abdulaziz Çaviş, Anglikan Kilisesine Cevap, çev. Mehmet Akif Ersoy (Ankara: Diyanet İşleri Başkanlığı Yayınları, 1974), 161-175. 
kilenmeleri, çabuk tepki vermeleri gibi kadınların biyo-psikolojik farklılıklarından kaynaklanmaktadır. ${ }^{60}$

Şeriati, konuyu din ve geleneğin birbirine eklemlenen yapısı çerçevesinde ele alır. Ona göre kadının haklarını gasp eden, din değil gelenektir. Geleneksel toplumlar eskilerden miras kalan her şeyi kutsallaştırıp yüceltmişler, 'kadim' olana 'dinî' bir hüviyet kazandırmışlardır. Toplum sürekli değişmekte, kadın da bu değişimden etkilenmektedir. İslam, değişime uyum sağlayacak dinamik yapıdaki bir dindir. Din ve geleneğin karıştırılması İslam'ın eskimeyen bu yapısına zarar verir. 61

İslamiyet öncesindeki Arap toplumunda tüm insanî değerler erkeğe mahsus kılınmış, kadın her türlü fazilet ve asaletten mahrum bırakılmıştır. Kız çocuğunun aileye yük olarak görüldüğü, yaşam hakkı tanınmadığı bir zaman ve zeminde, $\mathrm{Hz}$. Peygamberin soyu kız çocuğundan devam etmiştir. İslam, O’na ebter (soyu kesik) diyen kafirlere karşı O'nu kevser (hayrın ve bereketin bolluğu) olarak sunmuş, bu suretle zamanın vicdanında büyük bir devrim yapmıştır. ${ }^{62}$

Referansını İslam'dan almış olmakla beraber kimi noktalarda eleştirel bir tavır içinde olan Amine Vedud, Kur'an'ı, kadını güçlendiren evrensel nitelikte kutsi bir kaynak olarak değerlendirir. Ona göre, kadını kısıtlayan Kur'an değil, onun yorumlarıdır. ${ }^{63}$ Vedud, kadın meselesiyle ilgili olarak Kur'an tefsirlerini geleneksel, tepkisel ve bütüncül olarak üçe ayırır. Geleneksel tefsirlerin en karakteristik özelliği erkekler tarafından yazılmış olmasıdır. Dolayısıyla bu durum; tefsirlerde erkeklere, onların deneyimlerine, ihtiyaçlarına ve bakış açılarına daha çok yer verildiği anlamına gelmektedir. Tepkisel tefsirler, genellikle çağdaş düşünürlerin yazdığı ve kadının Kur'an'da ele alınış şeklini eleştiren tefsirlerdir. Bunlar İslam'a ve Kur'an'a tamamen karşı bir duruş sergilerler. Üçüncü tefsir şekli ise diğerlerine göre yeni olan bütüncül tefsirlerdir. Bunlar kadın meselesi de dahil her konuda Kur'an'ın alternatif bakış açılarıyla yeniden tefsir edilmesi görüşünü benimser. Kur'an'ın bu yeni tefsirinde kullanılması gereken usul 'hermenötik'dir. Vedud'un önerdiği bu tefsir modeli, bir metni yorumlarken onun yazıldığı şartları, metnin gramer özelliklerini ve metnin bütününü dikkate almayı gerektirir. Hermenötik sayesinde Vedud, cinsiyete dayalı olarak algılanan bazı konuları cinsiyetsiz terimlerle çözümleme, evrensel kabul edilen bazı meselelerin de sınırlılıklarını tespit etme yoluna gitmiştir. Kur'an'ı sadece belirli bir kültürün sınırları içinde değerlendirmek onun evrensellik özelliğine ters düşer. ${ }^{64}$

İslam'ın kutsal kaynaklarının alternatif bir okumayla yeniden ele alınmasını öneren yazarlardan bir diğeri Hidayet Şefkatli Tuksal'dır. Tuksal, İslam'ın Kur'an'dan sonraki en önemli kaynağı olan hadislerde, kadın karşıtı söyleme mal-

60 Çaviş, Anglikan Kilisesine Cevap, 176-180.

61 Ali Şeriati, Kadın (Fatıma Fatımadır), çev. Esra Özlük (Ankara: Fecr Yayınları, 2011), 54-56.

62 Şeriati, Kadın (Fatıma Fatımadır), 124-127.

63 Amine Vedud Muhsin, Kur'an ve Kadın (İstanbul: İz Yayıncılık, 1997), 17-18.

64 Vedud Muhsin, Kur'an ve Kadın, 22-29. 
zeme olan rivayetleri, ait oldukları dönem ve bağlam içinde değerlendirmiş, bu rivayetlerdeki ataerkil etkileri incelemiştir. Böylece kadını eksik ve suçlu gösteren ifadelerin gerçekten hadis mi yoksa kültürel önyargıların hadisleştirilmiş bir görüntüsü mü olduğunu oraya çıkarmayı amaçlamıştır. ${ }^{65}$

Tuksal'a göre nakledilen hadislerde mananın esas alınması, anlama ve yorumlamada farklılıklar ortaya çıkarmış, bu farklılıklar hadislerin meşrulaştırıcı gücünün etkisiyle sorgulanmamıştır. Aynı konuda rivayet edilen hadisler birbiriyle karşılaştırıldığında, râvilerin rivayetlerdeki tasarrufu ortaya çıkmaktadır. ${ }^{66}$

Türkiye'de kadının konumuyla ilgili tartışmalar, modernleşmenin başlangıcı sayılan Tanzimat Döneminden itibaren başlamıştır. Bu dönemde modernleşme, İslami kültürü benimseyen bir toplumda Doğu-Batı çatışmasını da beraberinde getirmiştir. Bu çatışmanın yaşandığı alanlardan biri de "kadının toplumdaki yeri" dir. Kadının toplumdaki konumunun ele alınması bir yönüyle kadının yaşam koşullarını iyileştirme gayretini, diğer yönüyle de modernleşmenin ölçütü olmayı ifade eder. ${ }^{67}$ Türkiye'de kadın konusunda yapılan çalışmalar önceleri sorun odaklı olarak yönünü belirlemiş, zamanla söylemsel ve kurumsal bir hal almaya başlamıştır. ${ }^{68}$ Cumhuriyet dönemiyle birlikte kadınlar lehine yapılan çeşitli yasal düzenlemeler, Cumhuriyetçi modernlik, başörtüsü ve kadınların kamusal alanda görünürlüğü gibi konular tartışmaların odak noktasını oluşturmuştur. ${ }^{69}$ Yapılan akademik çalışmalarda mahrem, tesettür, sekülerleşme, modernleşme ve kadın, sosyal hayat ve kadın, aile hayatı ve kadın, dindar kadın gibi konuların ilgi odağı olduğu görülmüştür. ${ }^{70}$

\section{Araştırmanın Yöntemi}

Bu çalışma Çorum II Müftülüğüne bağlı merkez ve merkeze bağlı köylerde çalışan din görevlilerinin toplumsal cinsiyet rollerine ilişkin tutumlarını belirlemek amacıyla yapılmış; amacına göre tanımlayıcı, takip ettiği yola göre nicel, kapsadığı zaman açısından kesitsel ve temel felsefe olarak temel bir araştırmadır.

Araştırma kapsamında din görevlilerinin toplumsal cinsiyet rollerine ilişkin tutumlarının; bağımsız değişken olarak ele alınan yaş, cinsiyet, eğitim, medeni durum, görev, görev yeri, görev yılı, eşinin eğitim durumu ve eşinin çalışıp çalışmaması gibi sosyo-demografik etmenlerle ilişkileri çerçevesinde betimlemesi yapılmıştır. Bu betimlemeyi gerçekleştirmek için kullanılan nicel araştırma tasa-

65 Hidayet Şefkatli Tuksal, Kadın Karşıtı Söylemin Islam Geleneğindeki Izdüşümleri (Ankara: Kitabiyat, 2000), 9.

66 Tuksal, Kadın Karşıtı Söylemin İslam Geleneğindeki Izdüşümleri, 236-238.

67 Nilüfer Göle, Modern Mahrem (İstanbul: Metis Yayınları, 1991), 11-18.

68 Feyza Ceyhan Çoştu, "II. Meşrutiyet Aydınlarından Baha Tevfik ve Kadın”, Uluslararası Sosyal Araştırmalar Dergisi 13/75 (2020), 436-441.

69 Deniz Kandiyoti, "Türkiye'de Toplumsal Cinsiyet ve Kadın Çalışmaları: Gelecek İçin Geçmişe Bakış”, Birkaç Arpa Boyu, 21 Yüzyıl'a Girerken Türkiye'de Feminist Çalışmalar: Prof. Dr. Nermin Abadan Unat'a Armağan, ed. Serpil Sancar (İstanbul: Koç Üniversitesi Yayınları, 2011), 1/46-48.

70 Fatma Kenevir - Şeyda Koçak Kurt, “Türkiye'de Toplumsal Cinsiyet ve Din Temalı Tez Çalışmaları Üzerine Bir Değerlendirme", Dini Araştırmalar 19/49 (2016), 358. 
rımının içeriği anket ve ölçekten meydana gelmektedir. Araştırmanın desenini genel ve istatistiki tarama araştırması oluşturmaktadır.

Araştırmanın evrenini Çorum III Müftülüğüne bağlı merkez ve köylerdeki kurumlarda (cami, Kur'an kursu) çalışan 527 din görevlisi oluşturmaktadır. Araştırmada örneklem seçimine gidilmemiş, tüm evrene ulaşılmaya çalışılmıştır. Ulaşılan katılımcıgrubuaraştırmanın örnekleminioluşturmaktadır. Katılımcılardan araştırmanın yapıldığı tarihte raporlu veya izinli olan 75, yurt dışında görevli olan 2, anketi doldurmayan 176 kişi araştırma kapsamı dışında kalmıştır. Anketi yanlış veya eksik dolduran 18 kişi de araştırmaya dahil edilmemiştir. Sonuç olarak ulaşılan 256 katılımcı araştırmanın örneklemini meydana getirmiştir.

Araştırmada kullanılan verilerin elde edilmesinde araştırmacılar tarafından hazırlanan katılımcıların sosyo-demografik özelliklerini belirlemeye yönelik sorular ve Simge Zeyneloğlu tarafından geliştirilen 'Toplumsal Cinsiyet Rolleri Tutum Ölçeği' (TCRTÖ) 71 kullanılmıştır. Zeyneloğlu tarafından geliştirilen Toplumsal Cinsiyet Rolleri Tutum Ölçeğinin Cronbach a güvenirlik katsayısı 0,92'dir. Bu değer ölçeğin alt boyutlarında 0,80 ile 0,72 arasında değiş̧mektedir. Bu çalışmada Cronbach a güvenirlik katsayısı 0,70 olarak belirlenmiştir. Araştırmanın yapıldığı zaman, örneklem farklılığı ve büyüklüğü gibi faktörlerin Cronbach a güvenirlik katsayısında etkili olduğu düşünülmektedir.

Sosyo-demografik özellikleri belirlemeye yönelik anket katılımcıların cinsiyet, yaş, eğitim durumu, medeni durum, eşin eğitim durumu, eşin çalışıp çalışmaması, görev türü, görev yeri, görevde hizmet yılını belirlemek üzere hazırlanmıştır. Katılımcıların toplumsal cinsiyet rollerine ilişkin tutumlarını ölçen TCRTÖ 0-5 arası puanlanmış beşli likert ölçeği şeklindedir. TCRTÖ, 38 madde ve beş alt boyuttan oluşmaktadır. Katılımcılar bu ölçekten en az 38, en çok 190 puan alabilecektir. Ölçekten alınacak düşük puan katılımcının toplumsal cinsiyet rolleri karşısında geleneksel, yüksek puan ise eşitlikçi bir tavır içinde olduğunu ifade etmektedir.

Veri toplama araçları, katılımcılara 15.03.2021 ve 30.03.2021 tarihleri arasında uygulanmıştır. İmam-hatip ve müezzin-kayyımlara, aylık yapılan rutin toplantılar yoluyla ulaşılmıştır. Kur'an kursu öğreticileri için planlanmış bir toplantı olmadığından ve ihtiyaç odaklı kurslar (yetişkinler için) pandemi nedeniyle yüz yüze eğitim vermediklerinden veri toplama aracı Google form aracılığı ile elektronik ortamda uygulanmıştır. Yüz yüze eğitim veren 0-6 yaş ve hafız yetiştiren Kur'an kursları ise mesai saatleri içinde ziyaret edilerek din görevlilerine ulaşılmış ve veriler toplanmıştır. Katılımcıların veri toplama araçlarını doldurmaları yaklaşık 10-15 dakika sürmüştür.

Verilerin toplanması tamamlandıktan sonra elde edilen veriler gözden geçirilmiş, yanlış ya da eksik doldurulan sayfalar ayıklanmıştır. Daha sonra her

71 Simge Zeyneloğlu, Ankara'da Hemşirelik Öğrenimi Gören Üniversite Öğrencilerinin Toplumsal Cinsiyet Rollerine Illişkin Tutumları (Ankara: Hacettepe Üniversitesi, Doktora Tezi, 2008), 126-127. 
katılımcının doldurduğu ankete bir sayı verilmiştir. Veriler, bu sayıların sırasına göre IBM SPSS Statistics Version 25 programına aktarılmıştır. Elektronik ortamda elde edilen veriler diğer verilerin altına kopyalanmıştır. Veriler değerlendirilmeden önce verilerin normal dağılım gösterip göstermediği araştırılmış; bu kapsamda, verilerin basıklık (kurtosis) ve çarpıklık (skewness) değerlerine bakılmıştır. Verilerin -1 ile +1 değerleri arasında dağıldığı görülmüşsür. Ayrıca çarpıklık ve basıklık değerleri kendi standart hatasına bölünmüş, elde edilen değerin $\pm 3,29$ arasında olduğu tespit edilmiştir. Bu değerlere göre verilerin normal dağıldığı sonucuna varılmış, verilerin karşılaştırılmasında "ortalama değer"in kullanılmasına karar verilmiştir. Elde edilen verilerin istatistiksel analizi, T testi (Independent-Samples T Test), tek yönlü varyans analizi (Analysis of Variance, ONE-WAY-ANOVA), Tukey HSD (Post Hoc Multiple Comparisons) testleriyle ile yapılmıştır. İstatistiksel testlerin anlamlılık düzeyi için $p<0,05$ değeri kabul edilmiştir.

\section{Bulgular ve Yorum}

Araştırmanın bu bölümünde bağımsız değişkenlere göre din görevlilerinin toplumsal cinsiyet rollerine ilişkin tutumları analiz edilmiştir. Bu doğrultuda cinsiyet, yaş, öğrenim durumu, eşinin öğrenim durumu, görev türü, görev yeri ve görevde hizmet yılına göre din görevlilerinin toplumsal cinsiyet rollerine ait tutumları arasında anlamlı bir farklılık olup olmadığı araştırılmıştır.

\subsection{Din Görevlilerinin Sosyo-Demografik Özelliklerinin Dağılımına iliş̧kin Bulgular}

Aşağıda Tablo 1'de çalışmaya dahil olan din görevlilerinin sosyo-demografik özelliklerine göre dağılımı verilmiştir. Buna göre araştırmaya dahil olan toplam 256 din görevlisinin \%44,1'i kadın, \%55,9'u erkektir. Din görevlilerinin \%10,2'si 18-30, \%79,3'ü 31-50, \%10,5'i 51+ yaş aralığındadır. Toplanan verilere göre din görevlilerinin \%10,2'si lise \%45,2'si ön lisans, \%39,1'i lisans, \%5,5'i yüksek lisans ve doktora mezunudur. (Katılımcıların sosyo-demografik özelliklerini belirlemek üzere yapılan ankette lise ve imam-hatip lisesi mezunları sonuçta lise seviyesinde mezun oldukları için lise başlığı altında birleştirilmiştir.)

Araştırmaya katılan din görevlilerinin \%89,8'i evli, \%8,2'si bekar, \%2'si diğer (dul, eşinden ayrılmış) kategorisindedir. Eşlerin eğitim durumuna bakıldığında eşlerin \%27,4'ü ilkokul, \%10,3'ü ortaokul, \%18,9'u lise, \%11,2'si ön lisans, \%24,9'u lisans, \%7,3'ü lisansüstü (yüksek lisans-doktora) mezunudur. Eşin çalışma durumu incelendiğinde din görevlilerinin \%43,8'inin eşi çalışmakta, \%54,1'inin eşi çalışmamakta, \%2,1'i diğer (emekli vb.) kategorisinde yer almaktadır. Din görevlilerinin \%49,6'sı Kur'an kursu öğreticisi, \%38,3'ü imam, \%12,1'i müezzin olarak görev yapmaktadır. Bunlardan \%76,2'sinin görev yeri il merkezi, \%23,8'inin görev yeri ise merkeze bağlı köylerdir. Din görevlilerinin hizmet yılı incelendiğinde \%16,8'inin 1-5 yıl, \%25,8'inin 6-10 yıl, \%20,3'ünün 11-15 yıl, \%9,4'ünün 16-20 yıl, \%8,2'sinin 21-25 yıl, \%19,5'inin 26+ yıl hizmet yılı olduğu tespit edilmiştir. 
Tablo 1: Din Görevlilerinin Sosyo-Demografik Özelliklerinin Dağılımı $(n=256)$

\begin{tabular}{|c|c|c|c|}
\hline \multicolumn{2}{|c|}{ Sosyo-Demografik Özellikler } & \multirow{2}{*}{$\begin{array}{c}\text { Sayı(n) } \\
113 \\
\end{array}$} & \multirow{2}{*}{$\begin{array}{c}\% \\
44,1\end{array}$} \\
\hline Cinciuntiniz & Kadın & & \\
\hline Consiyetiniz & Erkek & 143 & 55,9 \\
\hline \multirow{3}{*}{ Yaşınız } & $18-30$ & 26 & 10,2 \\
\hline & $31-50$ & 203 & 79,3 \\
\hline & $51+$ & 27 & 10,5 \\
\hline \multirow{4}{*}{ Eğitim Durumunuz } & Lise & 26 & 10,2 \\
\hline & Ön Lisans (Yüksek Okul) & 116 & 45,2 \\
\hline & Lisans (Fakülte) & 100 & 39,1 \\
\hline & Yüksek Lisans- Doktora & 14 & 5,5 \\
\hline \multirow{3}{*}{ Medeni Durumunuz } & Evli & 230 & 89,8 \\
\hline & Bekar & 21 & 8,2 \\
\hline & Diğer & 5 & 2 \\
\hline \multirow{6}{*}{$\begin{array}{l}\text { Eşinizin Eğitim Durumu* } \\
n=230\end{array}$} & İlkokul & 64 & 27,4 \\
\hline & Ortaokul & 24 & 10,3 \\
\hline & Lise & 44 & 18,9 \\
\hline & Ön Lisans (Yüksek Okul) & 26 & 11,2 \\
\hline & Lisans (Fakülte) & 58 & 24,9 \\
\hline & Yüksek Lisans- Doktora & 17 & 7,3 \\
\hline \multirow{3}{*}{ Göreviniz } & Kur'an Kursu Öğreticisi & 127 & 49,6 \\
\hline & İmam-Hatip & 98 & 38,3 \\
\hline & Müezzin-Kayyım & 31 & 12,1 \\
\hline \multirow{2}{*}{ Görev yeriniz } & İl Merkezi & 195 & 76,2 \\
\hline & Köy & 61 & 23,8 \\
\hline \multirow{6}{*}{ Görevde Hizmet Yılınız } & $1-5 \mathrm{yll}$ & 43 & 16,8 \\
\hline & 6-10 yıl & 66 & 25,8 \\
\hline & $11-15 \mathrm{yll}$ & 52 & 20,3 \\
\hline & $16-20 \mathrm{yıl}$ & 24 & 9,4 \\
\hline & $21-25$ yıl & 21 & 8,2 \\
\hline & $26+y ı l$ & 50 & 19,5 \\
\hline
\end{tabular}

*Bu soruya sadece evli olanlar cevap vermiştir. 


\subsection{Katılımcıların Bazı Sosyo-Demografik Özelliklerine Göre Toplumsal Cinsiyet Rolleri Tutum Puanlarının Analizi}

Bu araştırmaya katılan din görevlilerinin TCRTÖ toplam puan ortalaması 129,92 'dir. Tablo 2'de de görüldüğü üzere araştırmada elde edilen bu sonuca göre, din görevlilerinin toplumsal cinsiyet rollerine ilişkin daha eşitlikçi bir tutum eğilimine sahip olduğu söylenebilir.

Din görevlilerinin TCRTÖ'nün alt boyutlarından aldıkları puan ortalamaları karşılaştırıldığında, en düşük puan ortalamasının 'geleneksel cinsiyet rolü'nde, ortalamalar bakımından en yüksek puanın ise 'kadın cinsiyet rolü' ve 'evlilikte cinsiyet rolü' alt boyutlarına ait olduğu görülmektedir. Bu durum din görevlilerinin toplumsal cinsiyet rollerine ilişkin genel olarak eşitlikçi bir tutum göstermekle beraber kimi durumlarda geleneksel bir eğilim gösterdikleri kanaatini oluşturmaktadır.

Tablo 2: Din Görevlilerinin TCRTÖ ve Alt Boyutlarından Aldıkları Puan Ortalamaları

\begin{tabular}{|l|c|c|c|c|c|}
\hline Ölçeğin Alt Boyutları & $\begin{array}{c}\text { Madde } \\
\text { Sayısı }\end{array}$ & $\begin{array}{c}\text { Sayı } \\
\text { (n) }\end{array}$ & Ortalama \pm s.s. & $\begin{array}{c}\text { Min. } \\
\text { Puan }\end{array}$ & $\begin{array}{c}\text { Max. } \\
\text { Puan }\end{array}$ \\
\hline Eşitlikçi Cinsiyet Rolü & 8 & 256 & $30,59 \pm 4,87$ & 16 & 40 \\
\hline Kadın Cinsiyet Rolü & 8 & 256 & $32,10 \pm 3,47$ & 21 & 40 \\
\hline Evlilikte Cinsiyet Rolü & 8 & 256 & $32,10 \pm 3,47$ & 21 & 40 \\
\hline Geleneksel Cinsiyet Rolü & 8 & 256 & $22,17 \pm 5,06$ & 8 & 34 \\
\hline Erkek Cinsiyet Rolü & 6 & 256 & $21,88 \pm 3,47$ & 10 & 30 \\
\hline TCRTÖ Toplam Puanı & 40 & 256 & $129,92 \pm 12,18$ & 97 & 161 \\
\hline
\end{tabular}

Aşağıda Tablo 3'te din görevlilerinin cinsiyetlerine göre TCRTÖ ve alt boyutlarına ait tutum puanlarının istatistiksel analizi verilmiştir. Din görevlilerinin TCRTÖ'den aldıkları toplam puanların cinsiyete göre farklılık gösterip göstermediği bağımsız örneklem t-testi ile analiz edilmiştir. Kadın ve erkek din görevlilerinin toplumsal cinsiyet rollerine ilişkin ölçek toplam puanı $(t=14,71, p=0,00$ $p<0,01)$ ile beş alt boyut yani eşitlikçi cinsiyet rolü alt boyutu $(t=10,4 p=0,00$, $p<0,01)$, kadın cinsiyet rolü alt boyutu ( $t=11,388, p=0,00, p<0,01)$, evlilikte cinsiyet rolü alt boyutu ( $t=11,38, p=0,00, p<0,01)$, geleneksel cinsiyet rolü alt boyutu $(t=7,52, p=0,00, p<0,01)$, erkek cinsiyet rolü alt boyutundan $(t=7,01, p=0,00$, $p<0,01)$ alınan tutum puanları karşılaştırıldığında, kadın din görevlilerinin, erkek din görevlilerinden daha yüksek bir ortalamaya sahip olduğu görülmektedir. TCRTÖ ve alt boyutlarında gruplar arasında yüksek derecede anlamlı bir farklılık tespit edilmiştir. 
Tablo 3: Cinsiyete Göre Toplumsal Cinsiyet Rolleri Tutum Puanlarının İstatistiksel Analizi

\begin{tabular}{|c|c|c|c|c|c|c|c|}
\hline & Cinsiyet & $\mathbf{n}$ & $x$ & $\mathbf{S}$ & Sd & $\mathbf{T}$ & p \\
\hline \multirow{2}{*}{$\begin{array}{l}\text { Eşitlikçi } \\
\text { Cinsiyet Rolü }\end{array}$} & Kadın & 113 & 33,58 & 3,85 & \multirow{2}{*}{254} & \multirow{2}{*}{10,40} & \multirow{2}{*}{0,00} \\
\hline & Erkek & 143 & 28,23 & 4,26 & & & \\
\hline \multirow{2}{*}{$\begin{array}{l}\text { Kadın } \\
\text { Cinsiyet Rolü }\end{array}$} & Kadın & 113 & 34,33 & 2,48 & \multirow{2}{*}{253,99} & \multirow{2}{*}{11,38} & \multirow{2}{*}{0,00} \\
\hline & Erkek & 143 & 30,34 & 3,12 & & & \\
\hline \multirow{2}{*}{$\begin{array}{l}\text { Evlilikte } \\
\text { Cinsiyet Rolü }\end{array}$} & Kadın & 113 & 34,33 & 2,48 & \multirow{2}{*}{253,99} & \multirow{2}{*}{11,38} & \multirow{2}{*}{0,00} \\
\hline & Erkek & 143 & 30,34 & 3,12 & & & \\
\hline \multirow{2}{*}{$\begin{array}{l}\text { Geleneksel } \\
\text { Cinsiyet Rolü }\end{array}$} & Kadın & 113 & 24,60 & 4,87 & \multirow{2}{*}{254} & \multirow{2}{*}{7,52} & \multirow{2}{*}{0,00} \\
\hline & Erkek & 143 & 20,25 & 4,35 & & & \\
\hline \multirow{2}{*}{$\begin{array}{l}\text { Erkek } \\
\text { Cinsiyet Rolü }\end{array}$} & Kadın & 113 & 23,46 & 2,83 & \multirow{2}{*}{254} & \multirow{2}{*}{7,01} & \multirow{2}{*}{0,00} \\
\hline & Erkek & 143 & 20,64 & 3,44 & & & \\
\hline \multirow{2}{*}{$\begin{array}{l}\text { Ölçek } \\
\text { Toplam Puan }\end{array}$} & Kadın & 113 & 139,20 & 9,21 & \multirow{2}{*}{254} & \multirow{2}{*}{14,71} & \multirow{2}{*}{0,00} \\
\hline & Erkek & 143 & 122,58 & 8,77 & & & \\
\hline
\end{tabular}

t: Independents Samples-T Test

Bu veriler, kadın din görevlilerinin, erkek din görevlilerine göre toplumsal cinsiyet rollerine ilişkin daha eşitlikçi bir tutum içinde olduklarını göstermektedir. Toplumsal cinsiyet kavramının cinsiyetler arasındaki eşitliksiz güç ilişkilerine vurgu yapması ve bu eşitliksizliğin daha çok kadınlar aleyhine tezahür etmesi kadınların toplumsal cinsiyet rollerine ilişkin tutumlarda daha eşitlikçi olmasını açıklamaktadır. Bu duruma erkekler açısından bakıldığında geleneksel tutumlardan uzaklaşarak eşitlikçi tutumlara yönelmek, erkekler için aynı zamanda elde edilen güç ve otoritenin de paylaşımı anlamına geleceği için erkeklerin kadınlara göre daha geleneksel bir tutum içinde olduğunu söylemek mümkündür.

Ülkemizde yapılan saha çalışmalarına bakıldığında da benzer sonuçlara ulaşıldığı görülmektedir: Tam, diyanet çalışanlarının toplumsal cinsiyet rollerine ilişkin tutumlarına yönelik yaptığı çalışmada kadın diyanet çalışanlarının erkek diyanet çalışanlarına göre daha yüksek tutum puanlarına sahip olduklarını belirlemiştir. ${ }^{72}$ Benzer şekilde Keskin ilahiyat fakültesi öğrencilerinin toplumsal cinsiyet rollerine ilişkin tutumlarını incelediği çalışmasında kız öğrencilerin, kadınları ikinci planda bırakan ifadelere erkeklerden daha fazla karşı çıktıklarını; erkek öğrencilerin

72 Gülşah Tam, Diyanet Çalısanlarının Toplumsal Cinsiyet Rollerine Illişkin Tutumları (Mersin: Mersin Üniversitesi, Yüksek Lisans Tezi, 2020), 22. 
ise kendilerini ön plana çıkaran ifadelere daha fazla katıldığını tespit etmiştir. ${ }^{73}$ Ünalan'ın kütüphane çalışanları üzerine yaptığı çalışmada kadınların TCRTÖ’ye ait puan ortalamaları erkeklerden 20 puan fazla olduğu görülmüştür. ${ }^{74}$ Yapıcı din ve dindarlıkla toplumsal cinsiyet arasındaki ilişkiyi incelediği çalışmasında yükseköğretimdeki erkek öğrencilerin ataerkil toplumsal cinsiyet stereotiplerini kız öğrencilere göre daha fazla benimsedikleri sonucuna ulaşmıştır. Bu çalışmaya göre kızlar kısmen ataerkil kültür kodları içinde düşünüyor olmakla beraber ataerkil yapının kendilerine uygun gördüğü rolleri de sorgulamaya başlamışlardır. ${ }^{75}$ Bununla beraber Bekleviç'in araştırma görevlisi doktorlar üzerine yaptığı çalışma sonucunda kadınlarla erkekler arasında, çalışma yaşamında toplumsal cinsiyet rollerine ilişkin tutumlar arasında anlamlı bir farklılık bulunmamıştır. Araştırmaya katılanların öğrenim seviyelerinin yüksek olmasının bu durumu açıkladığı düşünülmektedir. ${ }^{76}$

Aşağıda Tablo 4'te din görevlilerinin yaşlarına göre TCRTÖ ve alt boyutlarına ait tutum puanlarının istatistiksel analizi verilmiştir. Ölçek toplam puan verilerine göre farklı yaş gruplarındaki din görevlilerinin toplumsal cinsiyet rollerine ilişkin tutumları arasında anlamlı bir farklılık bulunmuştur ( $F=5,71, p=0,04, p<0,05)$. Farklılıkların hangi gruplar arasında olduğunu belirlemeye yönelik yapılan Tukey HSD testi sonuçlarına göre 51 yaş ve üzerindeki $(122,92)$ din görevlileri ile 18-30 yaş $(133,07)$ ve $31-50$ yaş $(130,44)$ aralığındaki din görevlileri arasında anlamlı bir fark tespit edilmiştir. Bu verilere göre, 50 yaş altındaki katılımcıların toplumsal cinsiyet rollerine ilişkin daha eşitlikçi tutuma sahip olduğu söylenebilir.

Ölçek alt boyutlarından eşitlikçi cinsiyet rolü alt boyutunda ( $F=3,93, p=0,02$, $\mathrm{p}<0,05)$ gruplar arası puan ortalamalarında anlamlı farklılaşma tespit edilmiş ve bu farklılaşma 18-30 yaş $(31,92)$ grubundaki din görevlileri ile 51 yaş ve üstü $(28,37)$ din görevlileri arasında gözlemlenmiştir. Yine, kadın cinsiyet rolü alt boyutu $(F=5,32, p=0,00, p<0,01)$ ve evlilikte cinsiyet rolü alt boyutlarında ( $F=5,32$, $p=0,00, p<0,05)$ da gruplar arası puan ortalamalarında anlamlı farklılaşma tespit edilmiş ve bu farklılaşmanın 51 üstü yaş grubu ile 18-30 yaş ve 31-50 yaş grupları arasında olduğu tespit edilmiştir. Buna karşın, TCRTÖ'nün alt boyutlarından geleneksel cinsiyet rolü $(F=0,53, p=0,58, p>0,05)$ ve erkek cinsiyet rolü alt boyutlarında $(F=1,38, p=0,25, p>0,05)$ gruplar arasında anlamlı farklılaşma görülmemektedir.

73 Fatma Keskin, Ilahiyat Fakültesi Öğrencilerinin Toplumsal Cinsiyet Rollerine Iliş̧kin Tutumları (Konya: Necmettin Erbakan Üniversitesi, Yüksek Lisans Tezi, 2019), 116.

74 Eda Ünalan, Türkiye'deki Üniversite Kütüphanelerinde Çalışan Kütüphanecilerin Toplumsal Cinsiyet Algısı (Ankara: Ankara Üniversitesi, Yüksek Lisans Tezi, 2020), 53.

75 Yapıcı, Toplumsal Cinsiyet Din ve Kadın, 139.

76 Arzum Çelik Bekleviç, Bir Üniversite Hastanesi Araştırma Görevlilerinin Toplumsal Cinsiyet Rolleri Tutum Ölçeği ve Çalışma Yaşamında Toplumsal Cinsiyet Rolleri Algısının Değerlendirilmesi (Zonguldak: Bülent Ecevit Üniversitesi, Yüksek Lisans Tezi, 2013), 31. 
Tablo 4: Yaşa Göre Toplumsal Cinsiyet Rolleri Tutum Puanlarının İstatistiksel Analizi

\begin{tabular}{|c|c|c|c|c|c|c|c|c|}
\hline & Yaş & $\mathbf{n}$ & $x$ & $\mathbf{S}$ & Sd & $\mathbf{F}$ & $\mathbf{p}$ & $\begin{array}{c}\text { Grp. Ar. } \\
\text { Fark. }\end{array}$ \\
\hline \multirow{3}{*}{$\begin{array}{l}\text { Eşitlikçi } \\
\text { Cinsiyet } \\
\text { Rolü }\end{array}$} & $18-30$ & 26 & 31,92 & 4,43 & \multirow{3}{*}{$2 / 255$} & \multirow{3}{*}{3,93} & \multirow{3}{*}{0,02} & a \\
\hline & $31-50$ & 203 & 30,71 & 4,94 & & & & $a b$ \\
\hline & 51 ve üstü & 27 & 28,37 & 4,12 & & & & $\mathrm{~b}$ \\
\hline \multirow{3}{*}{$\begin{array}{l}\text { Kadın } \\
\text { Cinsiyet } \\
\text { Rolü }\end{array}$} & $18-30$ & 26 & 32,34 & 3,79 & \multirow{3}{*}{$2 / 255$} & \multirow{3}{*}{5,32} & \multirow{3}{*}{0,00} & a \\
\hline & $31-50$ & 203 & 32,34 & 3,41 & & & & a \\
\hline & 51 ve üstü & 27 & 30,07 & 3,03 & & & & $\mathrm{~b}$ \\
\hline \multirow{3}{*}{$\begin{array}{l}\text { Evlilikte } \\
\text { Cinsiyet } \\
\text { Rolü }\end{array}$} & $18-30$ & 26 & 32,34 & 3,79 & \multirow{3}{*}{$2 / 255$} & \multirow{3}{*}{5,32} & \multirow{3}{*}{0,00} & a \\
\hline & $31-50$ & 203 & 32,34 & 3,41 & & & & a \\
\hline & 51 ve üstü & 27 & 30,07 & 3,03 & & & & $\mathrm{~b}$ \\
\hline \multirow{3}{*}{$\begin{array}{l}\text { Geleneksel } \\
\text { Cinsiyet } \\
\text { Rolü }\end{array}$} & $18-30$ & 26 & 22,34 & 5,45 & \multirow{3}{*}{$2 / 255$} & \multirow{3}{*}{0,53} & \multirow{3}{*}{0,58} & a \\
\hline & $31-50$ & 203 & 22,27 & 5,04 & & & & a \\
\hline & 51 ve üstü & 27 & 21,22 & 4,92 & & & & a \\
\hline \multirow{3}{*}{$\begin{array}{l}\text { Erkek } \\
\text { Cinsiyet } \\
\text { Rolü }\end{array}$} & $18-30$ & 26 & 22,19 & 3,86 & \multirow{3}{*}{$2 / 255$} & \multirow{3}{*}{1,38} & \multirow{3}{*}{0,25} & $\mathrm{a}$ \\
\hline & $31-50$ & 203 & 21,98 & 3,42 & & & & a \\
\hline & 51 ve üstü & 27 & 20,85 & 3,48 & & & & $a$ \\
\hline \multirow{3}{*}{$\begin{array}{l}\text { Ölçek } \\
\text { Toplam } \\
\text { Puan }\end{array}$} & $18-30$ & 26 & 133,07 & 12,45 & \multirow{3}{*}{$2 / 255$} & \multirow{3}{*}{5,71} & \multirow{3}{*}{0,04} & $\mathrm{a}$ \\
\hline & $31-50$ & 203 & 130,44 & 12,21 & & & & $a$ \\
\hline & 51 ve üstü & 27 & 122,92 & 9,22 & & & & $b$ \\
\hline
\end{tabular}

${ }^{*}$ Farklı harfler gruplar arası önemli farklılığı göstermektedir. $(p<0,05)$

Bu verilere göre din görevlilerinin yaşları arttıkça çoğunlukla TCRTÖ puanları azalmaktadır. Özellikle 51 yaş ve üstü gruptaki din görevlilerinin diğer yaş grubundakilere göre daha geleneksel bir tutum içinde olduğu görülmektedir. Din görevlileri içindeki genç neslin, toplumsal cinsiyet rollerine ilişkin tutumlar açısından daha yenilikçi ve eşitlikçi olduğu söylenebilir.

Tablo 4'teki verilerden de anlaşılacağı üzere, araştırmaya katılan din görevlileri, toplumsal cinsiyet rollerine ilişkin genel olarak eşitlikçi bir tavır içinde olmalarına rağmen, bazı durumlarda gelenekçi bir tutuma sahiptirler. Yıllarca toplumun kültürel kodlarının içine yerleşen toplumsal cinsiyet algısının hemen değişmesi beklenemez. Kültürün belirlediği ve besleyerek devam ettirdiği bu roller belli bir yoğunlukta varlığını devam ettirmektedir. 
Ülkemizde yapılan benzer saha araştırmalarında, yaşın ilerlemesi ile toplumsal cinsiyet rollerine ilişkin tutumların daha gelenekçi olduğu tespit edilmiştir. ${ }^{77}$ Yapıcı, üniversite öğrencileri arasında yaptığı çalışmasında yaşın büyümesi ile kadının doğurganlık merkezli algılanması arasında pozitif bir ilişki olduğu sonucuna ulaşmıştır. ${ }^{78}$ Bu bulgular bizim ulaştığımız sonuçlarla da paralellik göstermektedir. Bununla beraber daha ileri yaşlardakilerin toplumsal cinsiyet rollerine ilişkin tutumlarının daha eşitlikçi olduğunu gösteren çalışmalar da mevcuttur. ${ }^{79}$

Aşağıda Tablo 5'te din görevlilerinin eğitim durumlarına göre TCRTÖ ve alt boyutlarına ait tutum puanlarının istatistiki analizi yer almaktadır. Tablodaki verilere göre, farklı eğitim seviyelerindeki din görevlilerinin toplumsal cinsiyet rollerine ilişkin toplam tutum puanları ( $F=14,08, p=0,00, p<0,01)$ arasında yüksek derecede anlamlı bir farklılık olduğu görülmektedir. Farklılaşma, lise $(124,84)$ ve ön lisans $(126,06)$ mezunu din görevlileri ile lisans $(134,68)$ ve lisansüstü $(137,35)$ mezunları arasında tespit edilmiştir. Buna göre, din görevlilerinin eğitim seviyesi yükseldikçe toplumsal cinsiyet rollerine ilişkin tutumlarının daha eşitlikçi olduğu söylenebilir.

Tablo 5: Eğitim Durumuna Göre Toplumsal Cinsiyet Rolleri Tutum Puanlarının İstatistiksel Analizi

\begin{tabular}{|c|c|c|c|c|c|c|c|c|}
\hline & $\begin{array}{l}\text { Eğitim } \\
\text { Durumu }\end{array}$ & $\mathbf{n}$ & $\mathbf{x}$ & S & Sd & $\mathbf{F}$ & $\mathbf{p}$ & $\begin{array}{c}\text { Grp. Ar. } \\
\text { Fark.* }\end{array}$ \\
\hline \multirow{4}{*}{ 氙 } & Lise & 26 & 28,19 & 4,61 & \multirow{4}{*}{$3 / 255$} & \multirow{4}{*}{9,41} & \multirow{4}{*}{0,00} & a \\
\hline & Ön Lisans & 116 & 29,53 & 4,67 & & & & $a b$ \\
\hline & Lisans & 100 & 32,03 & 4,60 & & & & $b c$ \\
\hline & Lisansüstü & 14 & 33,57 & 4,76 & & & & c \\
\hline \multirow{4}{*}{ 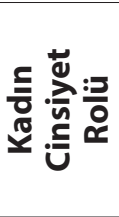 } & Lise & 26 & 30,88 & 3,40 & \multirow{4}{*}{$3 / 255$} & \multirow{4}{*}{7,71} & \multirow{4}{*}{0,00} & $a$ \\
\hline & Ön Lisans & 116 & 31,28 & 3,41 & & & & $a b$ \\
\hline & Lisans & 100 & 33,26 & 3,25 & & & & $\mathrm{~b}$ \\
\hline & Lisansüstü & 14 & 32,92 & 3,36 & & & & $a b$ \\
\hline \multirow{4}{*}{ 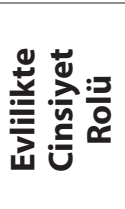 } & Lise & 26 & 30,88 & 3,40 & \multirow{4}{*}{$3 / 255$} & \multirow{4}{*}{7,71} & \multirow{4}{*}{0,00} & $a$ \\
\hline & Ön Lisans & 116 & 31,28 & 3,41 & & & & $a b$ \\
\hline & Lisans & 100 & 33,26 & 3,25 & & & & b \\
\hline & Lisansüstü & 14 & 32,92 & 3,36 & & & & $a b$ \\
\hline
\end{tabular}

77 Tam, Diyanet Çalışanlarııın Toplumsal Cinsiyet Rollerine Ilişkin Tutumları, 28.

78 Yapıcı, Toplumsal Cinsiyet Din ve Kadın, 144.

79 Serpil Özden ve Zehra Gölbaşı, “Sağlık Çalışanlarının Toplumsal Cinsiyet Rollerine Illişkin Tutumlarının Belirlenmesi", KOU Sağlık Bilimleri Dergisi 4/3 (2018), 99. 
Tablo 5 devam

\begin{tabular}{|c|c|c|c|c|c|c|c|c|}
\hline & $\begin{array}{l}\text { Eğitim } \\
\text { Durumu }\end{array}$ & $\mathbf{n}$ & 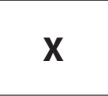 & $\mathbf{S}$ & Sd & $\mathbf{F}$ & $\mathbf{p}$ & $\begin{array}{l}\text { Grp. Ar. } \\
\text { Fark.* }\end{array}$ \\
\hline \multirow{4}{*}{ 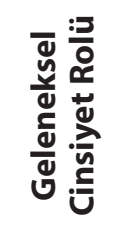 } & Lise & 26 & 20,84 & 3,09 & \multirow{4}{*}{$3 / 255$} & \multirow{4}{*}{7,23} & \multirow{4}{*}{0,00} & a \\
\hline & Ön Lisans & 116 & 20,95 & 5,46 & & & & $a$ \\
\hline & Lisans & 100 & 23,51 & 4,56 & & & & $a b$ \\
\hline & Lisansüstü & 14 & 25,14 & 4,80 & & & & $b$ \\
\hline \multirow{4}{*}{ 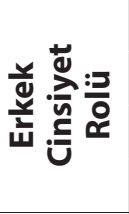 } & Lise & 26 & 21,80 & 2,99 & \multirow{4}{*}{$3 / 255$} & \multirow{4}{*}{5,68} & \multirow{4}{*}{0,00} & a \\
\hline & Ön Lisans & 116 & 21,00 & 3,34 & & & & $a b$ \\
\hline & Lisans & 100 & 22,68 & 3,55 & & & & $a b$ \\
\hline & Lisansüstü & 14 & 23,64 & 3,17 & & & & b \\
\hline \multirow{4}{*}{ 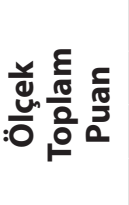 } & Lise & 26 & 124,84 & 8,27 & \multirow{4}{*}{$3 / 255$} & \multirow{4}{*}{14,08} & \multirow{4}{*}{0,00} & $a$ \\
\hline & Ön Lisans & 116 & 126,06 & 11,36 & & & & $a$ \\
\hline & Lisans & 100 & 134,68 & 11,66 & & & & b \\
\hline & Lisansüstü & 14 & 137,35 & 13,57 & & & & $b$ \\
\hline
\end{tabular}

*Farklı harfler gruplar arası önemli farklılığı göstermektedir. $(p<0,01)$

Tablo 5'teki verilere göre, TCRTÖ alt boyutlarında da çeşitli eğitim seviyelerindeki din görevlilerinin toplumsal cinsiyet rollerine ilişkin tutum puanları arasında yüksek derecede anlamlı farklılık görülmektedir. Gruplar arası farklılığın, eşitlikçi cinsiyet rolü alt boyutunda $(F=9,41, p=0,00, p<0,01)$ ve erkek cinsiyet rolü alt boyutunda $(F=5,68, p=0,001, p<0,01)$ lise mezunu $(28,19)$ din görevlileri ile lisansüstü $(33,57)$ mezunları arasında; kadın cinsiyet rolü alt boyutunda $(F=7,71$, $p=0,00, p<0,01)$ ve evlilikte cinsiyet rolü alt boyutunda $(F=7,71, p=0,00, p<0,01)$ lise mezunu ile lisans mezunları arasında; geleneksel cinsiyet rolü alt boyutunda ( $F=7,23, p=0,00, p<0,01)$ ise, lise mezunu $(20,84)$ ve ön lisans $(20,95)$ mezunu din görevlileri ile lisansüstü (yüksek lisans-doktora) mezunu olanlar $(25,14)$ arasında olduğu görülmektedir.

Bu sonuçlar, eğitim seviyesi ile toplumsal cinsiyet rollerine ilişkin tutumlar arasında pozitif bir ilişkinin olduğunu göstermektedir. Bu durumda eğitimin, bireyin toplumsal cinsiyet rolleri karşısındaki tutumu üzerinde önemli bir etkisi olduğunu söylemek mümkündür.

Benzer saha çalışmaları incelendiğinde eğitim düzeyi arttıkça bireyin toplumsal cinsiyet rollerine ilişkin eşitlikçi tutum puanlarında da artma olduğu tespit edilmiştir. ${ }^{80}$ Bu noktada din görevlilerinin almış oldukları din eğitiminin onların

80 Ünalan, Türkiye'deki Üniversite Kütüphanelerinde Çalışan Kütüphanecilerin Toplumsal Cinsiyet Algısı, 53. 
toplumsal cinsiyet rollerine ait tutumlarını gelenekçi yönde etkilemediği görülmektedir. Zira Yapıcı da İlahiyat fakültesi öğrencileriyle diğer alanlarda okuyan öğrenciler arasında 'kadını ev ve aile merkezli algılama', 'kadını cinsellik merkezli algılama', 'süregelen sosyo-kültürel cinsiyet algısı' boyutlarında anlamlı bir farklılık olmadığı sonucuna ulaşmıştır. Dolayısıyla yüksek seviyedeki din eğitimi adı geçen üç alanda da farklı bir tutum ve algı oluşturmamıştır. ${ }^{81}$

Aşağıda Tablo 6'da din görevlilerinin eşlerinin eğitim durumuna göre TCRTÖ ve alt boyutlarına ait tutum puanlarının istatistiki analizi verilmiştir. Ölçek toplam puan verilerine göre eşleri farklı öğrenim seviyelerindeki din görevlilerinin toplumsal cinsiyet rollerine ilişkin tutumları arasında yüksek derecede anlamlı bir farklılık olduğu görülmüştür $(F=26,1, p=0,00, p<0,01)$. Farklılaşma, eşi ortaokul $(121,04)$ mezunu, ön lisans $(130,03)$ mezunu, lisans $(138,92)$-lisansüstü $(121,44)$ mezunu olanlar arasında tespit edilmiştir.

Katılımcıların eşlerinin eğitim durumuna göre TCRTÖ tüm alt boyutlarında da din görevlilerinin toplumsal cinsiyet rollerine ilişkin tutumları arasında yüksek derecede anlamlı farklılık görülmüştür. Gruplar arası farklılıklar, eşitlikçi cinsiyet rolü alt boyutunda $(F=13,92, p=0,00, p<0,01)$ eşi ortaokul $(27,12)$ mezunu olanlar ile eşi lisans $(33,63)$ ve lisansüstü $(33,5)$ mezunu olanlar arasında; kadın cinsiyet rolü alt boyutu $(F=13,05, p=0,00, p<0,01)$ ve evlilikte cinsiyet rolü alt boyutunda ( $F=13,05, p=0,00, p<0,01)$ eşi ilkokul mezunu olanlar ile lisans ve lisansüstü mezunu olanlar arasında; geleneksel cinsiyet rolü alt boyutunda ( $F=10,54, p=0,00$, $p<0,01)$ eşi ilkokul $(20,4)$ ve lise $(20,04)$ mezunu olanlar ile eşi lisansüstü $(26,66)$ mezunu olanlar arasında; erkek cinsiyet rolü alt boyutunda $(F=7,62, p=0,00$, $p<0,01)$ ise eşi ilkokul $(20,81)$ ve ortaokul $(19,91)$ mezunu olanlar ile eşi lisans $(23,73)$ ve lisansüstü $(23,38)$ mezunu olanlar arasındadır.

Yapılan saha araştırmalarında da eşlerin eğitim seviyesinin toplumsal cinsiyet rollerine ilişkin tutumları etkilediği sonucuna ulaşılmıştır. ${ }^{82}$ Elde edilen sonuçlara göre kişinin eşinin eğitim seviyesi arttıkça daha eşitlikçi bir tutum gösterdiği tespit edilmiştir. Özellikle aile gibi toplumun temel yapısını oluşturan birliklerde eşlerin birbirinin duygu, düşünce ve davranışlarına etkilemesi kaçınılmaz bir durumdur. Hatta anne babanın eğitim seviyesinin artmasıyla çocukların da toplumsal cinsiyet rollerine ilişkin tutumlarının daha eşitlikçi olduğu yapılan çalışmalarda tespit edilmiştir. ${ }^{83}$ Buna göre, eşler arasında doğal olan cinsiyetler arası iş bölümünün hiyerarşik bir şekle dönüşmemesi ve çocukların daha eşitlikçi tutumlar geliştirmeleri açısından eğitim etkili bir araçtır.

81 Yapıcı, Toplumsal Cinsiyet Din ve Kadın, 142.

82 Tam, Diyanet Çalısanlarının Toplumsal Cinsiyet Rollerine Illişkin Tutumları, 30; Emel Kurşun, Samsun Halk Sağlığı Müdürlüğü'nde Çalışan Personelin Toplumsal Cinsiyet Rol Tutumlarının Belirlenmesi (Samsun: Ondokuz Mayıs Üniversitesi, Yüksek Lisans Tezi, 2016), 37.

83 Kurşun, Samsun Halk Sağlığı Müdürlüğü’nde Çalışan Personelin Toplumsal Cinsiyet Rol Tutumlarının Belirlenmesi, 37. 
Tablo 6: Eşin Eğitim Durumuna Göre Toplumsal Cinsiyet Rolleri Tutum Puanlarının İstatistiksel Analizi

\begin{tabular}{|c|c|c|c|c|c|c|c|c|}
\hline & $\begin{array}{c}\text { Eşin Eğitim } \\
\text { Durumu }\end{array}$ & $\mathbf{n}$ & $\mathbf{x}$ & $\mathbf{S}$ & Sd & $\mathbf{F}$ & $\mathbf{P}$ & $\begin{array}{l}\text { Grp. Ar. } \\
\text { Fark.* }\end{array}$ \\
\hline \multirow{6}{*}{ 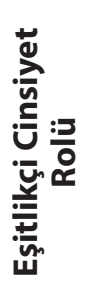 } & İlkokul & 64 & 28,82 & 4.1 & \multirow{6}{*}{$5 / 232$} & \multirow{6}{*}{13,92} & \multirow{6}{*}{0,00} & $a b$ \\
\hline & Ortaokul & 24 & 27,12 & 4.79 & & & & a \\
\hline & Lise & 43 & 28,81 & 4.43 & & & & $a b$ \\
\hline & Ön Lisans & 27 & 30,74 & 4.94 & & & & $\mathrm{bc}$ \\
\hline & Lisans & 57 & 33,63 & 4.11 & & & & c \\
\hline & Lisansüstü & 18 & 33,5 & 3.63 & & & & C \\
\hline \multirow{6}{*}{ 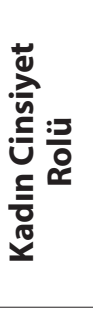 } & İlkokul & 64 & 30,4 & 2.97 & \multirow{6}{*}{$5 / 232$} & \multirow{6}{*}{13,05} & \multirow{6}{*}{0,00} & a \\
\hline & Ortaokul & 24 & 30,79 & 2.99 & & & & $a b$ \\
\hline & Lise & 43 & 30,97 & 3.36 & & & & $a b$ \\
\hline & Ön Lisans & 27 & 32,85 & 3.38 & & & & bc \\
\hline & Lisans & 57 & 33,98 & 2.68 & & & & C \\
\hline & Lisansüstü & 18 & 34,44 & 2.7 & & & & C \\
\hline \multirow{6}{*}{ 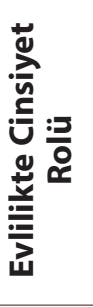 } & İlkokul & 64 & 30,4 & 2.97 & \multirow{6}{*}{$5 / 232$} & \multirow{6}{*}{13,05} & \multirow{6}{*}{0,00} & a \\
\hline & Ortaokul & 24 & 30,79 & 2.99 & & & & $a b$ \\
\hline & Lise & 43 & 30,97 & 3.36 & & & & $a b$ \\
\hline & Ön Lisans & 27 & 32,85 & 3.38 & & & & bc \\
\hline & Lisans & 57 & 33,98 & 2.68 & & & & c \\
\hline & Lisansüstü & 18 & 34,44 & 2.7 & & & & C \\
\hline \multirow{6}{*}{ 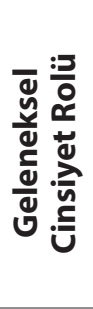 } & İlkokul & 64 & 20,4 & 4.5 & \multirow{6}{*}{$5 / 232$} & \multirow{6}{*}{10,54} & \multirow{6}{*}{0,00} & a \\
\hline & Ortaokul & 24 & 21,2 & 4.08 & & & & $a b$ \\
\hline & Lise & 43 & 20,04 & 4.35 & & & & a \\
\hline & Ön Lisans & 27 & 21,51 & 6.19 & & & & $a b$ \\
\hline & Lisans & 57 & 24,47 & 3.83 & & & & bc \\
\hline & Lisansüstü & 18 & 26,66 & 4.91 & & & & C \\
\hline \multirow{6}{*}{ 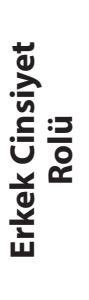 } & İlkokul & 64 & 20,81 & 3.65 & \multirow{6}{*}{$5 / 232$} & \multirow{6}{*}{7,62} & \multirow{6}{*}{0,00} & a \\
\hline & Ortaokul & 24 & 19,91 & 2.99 & & & & $a$ \\
\hline & Lise & 43 & 21,55 & 2.96 & & & & $a b$ \\
\hline & Ön Lisans & 27 & 21,77 & 3.84 & & & & $a b$ \\
\hline & Lisans & 57 & 23,73 & 2.97 & & & & $\mathrm{~b}$ \\
\hline & Lisansüstü & 18 & 23,38 & 2.78 & & & & $b$ \\
\hline
\end{tabular}


Tablo 6 devam

\begin{tabular}{|c|c|c|c|c|c|c|c|c|}
\hline & $\begin{array}{c}\text { Eşin Eğitim } \\
\text { Durumu }\end{array}$ & $\mathbf{n}$ & $\mathbf{x}$ & $\mathbf{S}$ & Sd & $\mathbf{F}$ & $\mathbf{P}$ & $\begin{array}{l}\text { Grp. Ar. } \\
\text { Fark.* }\end{array}$ \\
\hline \multirow{6}{*}{ 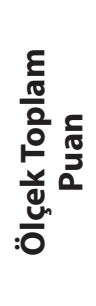 } & İlkokul & 64 & 123,7 & 8.51 & \multirow{6}{*}{$5 / 232$} & \multirow{6}{*}{26,1} & \multirow{6}{*}{0,00} & $a b$ \\
\hline & Ortaokul & 24 & 121,04 & 9.07 & & & & a \\
\hline & Lise & 43 & 124,88 & 10.28 & & & & $a b$ \\
\hline & Ön Lisans & 27 & 130,03 & 13.09 & & & & $b$ \\
\hline & Lisans & 57 & 138,92 & 9.19 & & & & C \\
\hline & Lisansüstü & 18 & 141,44 & 9.47 & & & & c \\
\hline
\end{tabular}

*Farklı harfler gruplar arası önemli farklılığı göstermektedir. $(p<0,01)$

Aşağıda Tablo 7'de din görevlilerinin görev türüne göre toplumsal cinsiyet rollerine ilişkin tutum puanlarının istatistiksel analizi verilmiştir. Tabloya göre hem TCRTÖ toplam puan ortalaması hem de beş alt boyut puan ortalamaları açısından, din görevlilerinin yürüttüğü görev türü ile toplumsal cinsiyet rollerine ilişkin tutumları arasında yüksek derecede anlamlı farklılıklar tespit edilmiştir. Farkın hangi gruplar arasında olduğunu belirlemek için yapılan analizde, ölçek toplam puan ve beş alt boyutta, Kur'an Kursu öğreticisi olarak görev yapan din görevlileri ile imam-hatip ve müezzin-kayyım olarak görev yapan din görevlileri arasında anlamlı farklılığın olduğu görülmüştür. Din görevlileri içinde imam-hatip ve müezzin kayyımların tamamının erkek; Kur'an kursu öğreticilerinin de büyük çoğunluğunun (\%90'ı) kadın olduğu düşünüldüğünde aslında burada görev türünden ziyade cinsiyetin toplumsal cinsiyet rollerine ilişkin tutumları etkilemede daha belirleyici olduğu anlaşılmaktadır. Zaten cinsiyetler arası puan farklılıklarıyla görev türleri arasındaki puan farklılıkları karşılaştırıldığında kadınların tutum puanlarının erkeklerden farkı \%16,62 iken Kur'an kursu öğreticilerinin imam-hatip ve müezzin kayyımlardan farkının \%15,7'dir. Bu oranlar birbirine oldukça yakındır.

Tablo 7: Görev Türüne Göre Toplumsal Cinsiyet Rolleri Tutum Puanlarının İstatistiksel Analizi

\begin{tabular}{|l|c|c|c|c|c|c|c|c|}
\hline & Görev Türü & $\mathbf{n}$ & $\mathbf{X}$ & $\mathbf{S}$ & $\mathbf{S d}$ & $\mathbf{F}$ & $\mathbf{p}$ & $\begin{array}{c}\text { Grp. Ar. } \\
\text { Fark.* }\end{array}$ \\
\hline \multirow{2}{*}{$\begin{array}{l}\text { Eşitlikçi } \\
\text { Cinsiyet } \\
\text { Rolü }\end{array}$} & Kur'an Kursu Öğ. & 127 & 33,03 & 4,24 & & & & $\mathrm{a}$ \\
\hline & İmam-Hatip & 98 & 28,52 & 4,11 & $2 / 255$ & 43,63 & 0,00 & $\mathrm{~b}$ \\
\hline & Müezzin-Kayyım & 31 & 27,12 & 4,42 & & & & $\mathrm{~b}$ \\
\hline \multirow{2}{*}{$\begin{array}{l}\text { Kadın } \\
\text { Cinsiyet } \\
\text { Rolü }\end{array}$} & Kur'an Kursu Öğ. & 127 & 33,96 & 2,78 & & & & $\mathrm{a}$ \\
\cline { 2 - 5 } & İmam-Hatip & 98 & 30,31 & 3,2 & $2 / 255$ & 50,1 & 0,00 & $\mathrm{~b}$ \\
\cline { 2 - 5 } & Müezzin-Kayyım & 31 & 30,12 & 2,77 & & & & $\mathrm{~b}$ \\
\hline
\end{tabular}


Tablo 7 devam

\begin{tabular}{|c|c|c|c|c|c|c|c|c|}
\hline & Görev Türü & $\mathbf{n}$ & $\mathbf{X}$ & $\mathbf{S}$ & Sd & $\mathbf{F}$ & $\mathbf{p}$ & $\begin{array}{l}\text { Grp. Ar. } \\
\text { Fark.* }\end{array}$ \\
\hline \multirow{3}{*}{$\begin{array}{l}\text { Evlilikte } \\
\text { Cinsiyet } \\
\text { Rolü }\end{array}$} & Kur'an Kursu Öğ. & 127 & 33,96 & 2,78 & \multirow{3}{*}{$2 / 255$} & \multirow{3}{*}{50,1} & \multirow{3}{*}{0,00} & a \\
\hline & İmam-Hatip & 98 & 30,31 & 3,2 & & & & $b$ \\
\hline & Müezzin-Kayyım & 31 & 30,12 & 2,77 & & & & $\mathrm{~b}$ \\
\hline \multirow{3}{*}{$\begin{array}{l}\text { Geleneksel } \\
\text { Cinsiyet } \\
\text { Rolü }\end{array}$} & Kur'an Kursu Öğ. & 127 & 23,91 & 5,16 & \multirow{3}{*}{$2 / 255$} & \multirow{3}{*}{18,8} & \multirow{3}{*}{0,00} & a \\
\hline & İmam-Hatip & 98 & 20,9 & 4,35 & & & & $b$ \\
\hline & Müezzin-Kayyım & 31 & 19,03 & 4,09 & & & & $\mathrm{~b}$ \\
\hline \multirow{3}{*}{$\begin{array}{l}\text { Erkek } \\
\text { Cinsiyet } \\
\text { Rolü }\end{array}$} & Kur’an Kursu Öğ. & 127 & 23,03 & 3,04 & \multirow{3}{*}{$2 / 255$} & \multirow{3}{*}{15,5} & \multirow{3}{*}{0,00} & a \\
\hline & İmam-Hatip & 98 & 20,88 & 3,48 & & & & $b$ \\
\hline & Müezzin-Kayyım & 31 & 20,35 & 3,66 & & & & $\mathrm{~b}$ \\
\hline \multirow{3}{*}{$\begin{array}{l}\text { Ölçek } \\
\text { Toplam } \\
\text { Puan }\end{array}$} & Kur'an Kursu Öğ. & 127 & 137,23 & 10,71 & \multirow{3}{*}{$2 / 255$} & \multirow{3}{*}{71,6} & \multirow{3}{*}{0,00} & a \\
\hline & İmam-Hatip & 98 & 123,42 & 8,56 & & & & $\mathrm{~b}$ \\
\hline & Müezzin-Kayyım & 31 & 120,48 & 9,3 & & & & $b$ \\
\hline
\end{tabular}

*Farklı harfler gruplar arası önemli farklılığı göstermektedir. $(p<0,01)$

Bu araştırmada, din görevlilerinin toplumsal cinsiyet rollerine ilişkin toplam puan ortalaması 129,92 olarak tespit edilmiştir. Bu çalışmada kullanılan TCRTÖ kullanılarak diğer mesleklere yönelik yapılan çalışmalar karşılaştırıldığında puan ortalamalarının kütüphane görevlilerinde $169,{ }^{84}$ halk sağlığı müdürlüğünde çalışan personelde $143,36^{85}$ hemşirelerde $154,86,{ }^{86}$ bir üniversite hastanesinde çalışan araştırma görevlilerinde $124^{87}$ olduğu görülmüştür.

84 Ünalan, Türkiye'deki Üniversite Kütüphanelerinde Çalışan Kütüphanecilerin Toplumsal Cinsiyet Algısı, 49.

85 Kurşun, Samsun Halk Sağlığı Müdürlüğ̈̈'nde Çalışan Personelin Toplumsal Cinsiyet Rol Tutumlarının Belirlenmesi, 28.

86 Serpil Özden-Zehra Gölbaşı, "Sağlık Çalışanlarının Toplumsal Cinsiyet Rollerine Illişkin Tutumlarının Belirlenmesi", KOU Sağlık Bilimleri Dergisi 4/3 (2018), 98.

87 Bekleviç, Bir Üniversite Hastanesi Araştırma Görevlilerinin Toplumsal Cinsiyet Rolleri Tutum Ölçeği ve Çalışma Yaşamında Toplumsal Cinsiyet Rolleri Algısının Değerlendirilmesi, 34. 
Tablo 8: Görev Yaptığı Yere Göre Toplumsal Cinsiyet Rolleri Tutum Puanlarının İstatistiksel Analizi

\begin{tabular}{|c|c|c|c|c|c|c|c|}
\hline & $\begin{array}{c}\text { Görev } \\
\text { Yaptığı Yer }\end{array}$ & $\mathbf{n}$ & $x$ & S & Sd & $\mathbf{t}$ & $\mathbf{P}$ \\
\hline \multirow{2}{*}{$\begin{array}{l}\text { Eşitlikçi } \\
\text { Cinsiyet Rolü }\end{array}$} & İl Merkezi & 195 & 30,88 & 5,01 & \multirow{2}{*}{254} & \multirow{2}{*}{1,72} & \multirow{2}{*}{0,85} \\
\hline & Köy & 61 & 29,65 & 4,28 & & & \\
\hline \multirow{2}{*}{$\begin{array}{l}\text { Kadın } \\
\text { Cinsiyet Rolü }\end{array}$} & İl Merkezi & 195 & 32,57 & 3,29 & \multirow{2}{*}{254} & \multirow{2}{*}{3,96} & \multirow{2}{*}{0,00} \\
\hline & Köy & 61 & 30,6 & 3,64 & & & \\
\hline \multirow{2}{*}{$\begin{array}{l}\text { Evlilikte } \\
\text { Cinsiyet Rolü }\end{array}$} & İl Merkezi & 195 & 32,57 & 3,29 & \multirow{2}{*}{254} & \multirow{2}{*}{3,96} & \multirow{2}{*}{0,00} \\
\hline & Köy & 61 & 30,6 & 3,64 & & & \\
\hline \multirow{2}{*}{$\begin{array}{l}\text { Geleneksel } \\
\text { Cinsiyet Rolü }\end{array}$} & III Merkezi & 195 & 22,5 & 5,34 & \multirow{2}{*}{135,83} & \multirow{2}{*}{2,19} & \multirow{2}{*}{0,03} \\
\hline & Köy & 61 & 21,11 & 3,92 & & & \\
\hline \multirow{2}{*}{$\begin{array}{l}\text { Erkek } \\
\text { Cinsiyet Rolü }\end{array}$} & İ Merkezi & 195 & 22,06 & 3,46 & \multirow{2}{*}{254} & \multirow{2}{*}{1,48} & \multirow{2}{*}{0,13} \\
\hline & Köy & 61 & 21,31 & 3,47 & & & \\
\hline \multirow{2}{*}{$\begin{array}{l}\text { Ölçek Toplam } \\
\text { Puan }\end{array}$} & îl Merkezi & 195 & 131,24 & 12,61 & \multirow{2}{*}{129,80} & \multirow{2}{*}{3,61} & \multirow{2}{*}{0,00} \\
\hline & Köy & 61 & 125,7 & 9,64 & & & \\
\hline
\end{tabular}

Tablo 8' de din görevlilerinin görev yaptığı yere göre TCRTÖ ve alt boyutlarına ait tutum puanlarının istatistiksel analiz sonuçları (t-test) yer almaktadır. Elde edilen ölçek toplam puanına göre il merkezi ve köyde görev yapan din görevlilerinin toplumsal cinsiyet rollerine ilişkin tutum puanları arasında yüksek derecede anlamlı bir farklılık ( $t=3,61, p=0,00 p<0,01)$ bulunmuştur. Ayrıca, TCRTÖ alt boyutlarından kadın cinsiyet rolü alt boyutu $(t=3,96, p=0,00, p<0,01)$, evlilikte cinsiyet rolü alt boyutu $(t=3,96, p=0,00, p<0,01)$ ve geleneksel cinsiyet rolü alt boyutlarında $(t=2,19, p=0,03, p<0,05)$ din görevlilerinin görev yaptığı yere göre elde edilen bulgular karşılaştırıldığında, il merkezinde görev yapan din görevlilerinin, köyde görev yapan din görevlilerinden daha yüksek tutum puanına sahip olduğu görülmektedir. Buna karşılık, eşitlikçi cinsiyet rolü alt boyutu $(t=1,72, p=0,85, p>0,05)$ ile erkek cinsiyet rolü alt boyundan $(t=1,48, p=0,13, p>0,05)$ alınan tutum puan ortalamalarında görev yapılan yere göre bir farklılaşma tespit edilememiştir. Yaşanılan yerin kimi tutumlar üzerinde etkili olduğu kimi tutumlarda ise etkili olmadığı söylenebilir.

Konuyla ilgili yapılan saha araştırmalarında da benzer sonuçlar elde edildiği görülmektedir. Önder ve arkadaşları öğrencilerin en uzun yaşadığı yerin toplumsal cinsiyet rollerine ilişkin tutumlarda anlamlı bir farklılık oluşturmadığı sonucu- 
na ulaşmıştır. ${ }^{88}$ Keskin'in çalışmasına göre ise ilde yaşayanlar kırsalda yaşayanlara kıyasla ev işlerinde kocanın karısına yardım etmesi gerektiğini düşünmektedir. ${ }^{89}$ Ünalan, katılımcıların en uzun süre yaşadığı yer açısından toplumsal cinsiyet rollerine ilişkin tutum puanlarını değerlendirmiş ve metropolde yaşayanların tutum puanlarının köyde yaşayanlara göre anlamlı bir farklılık gösterdiğini belirlemiştir. $^{90}$

Bu sonuçlara göre şehirde yaşayanların eğitim imkanlarından daha fazla yararlanma şansı bulmasının, kadının iş hayatında daha fazla yer alması ve ekonomik özgürlük açısından daha avantajlı fırsatlar elde etmesinin, kadın erkek ilişkileri ile cinsiyet rollerine ilişkin tutumlar üzerinde dönüştürücü bir etkisinin olduğu söylenebilir.

Tablo 9: Görevdeki Hizmet Yılına Göre Toplumsal Cinsiyet Rolleri Tutum Puanlarının İstatistiksel Analizi

\begin{tabular}{|c|c|c|c|c|c|c|c|c|}
\hline & Hizmet Yılı & $\mathbf{n}$ & $\mathbf{x}$ & $\mathbf{S}$ & Sd & $\mathbf{F}$ & $\mathbf{p}$ & $\begin{array}{l}\text { Grp. Ar. } \\
\text { Fark.* }\end{array}$ \\
\hline \multirow{6}{*}{ 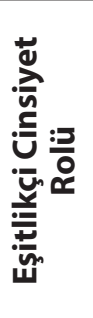 } & 1-5 YII & 43 & 32,04 & 4,05 & \multirow{6}{*}{$5 / 255$} & \multirow{6}{*}{11,99} & \multirow{6}{*}{0,00} & a \\
\hline & 6-10 YIl & 66 & 31,5 & 4,84 & & & & a \\
\hline & 11-15 Yıl & 52 & 32,61 & 4,07 & & & & a \\
\hline & 16-20 Yıl & 24 & 30,75 & 4,08 & & & & $a b$ \\
\hline & 21-25 Yıl & 21 & 25,9 & 4,5 & & & & c \\
\hline & 26 Yıl ve üstü & 50 & 27,94 & 4,58 & & & & bc \\
\hline \multirow{6}{*}{ 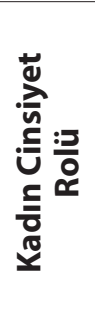 } & 1-5 Yll & 43 & 32,48 & 3,18 & \multirow{6}{*}{$5 / 255$} & \multirow{6}{*}{7,57} & \multirow{6}{*}{0,00} & $a b$ \\
\hline & 6-10 YII & 66 & 32,72 & 3,33 & & & & $a b$ \\
\hline & 11-15 YII & 52 & 33,71 & 3,24 & & & & $a$ \\
\hline & 16-20 Yıl & 24 & 31,2 & 4,02 & & & & bc \\
\hline & 21-25 YII & 21 & 31,23 & 2,8 & & & & $\mathrm{bc}$ \\
\hline & 26 Yıl ve üstü & 50 & 30,08 & 3,08 & & & & c \\
\hline
\end{tabular}

88 Ömer R. Önder vd., "Sağlık Kurumları Yöneticiliği Bölümü Öğrencilerinin Toplumsal Cinsiyet Rollerine ilişkin Tutumları", Ankara Sağlık Bilimleri Dergisi 2 (2013), 63.

89 Keskin, Illahiyat Fakültesi Öğrencilerinin Toplumsal Cinsiyet Rollerine illişkin Tutumları, 117.

90 Ünalan, Türkiye'deki Üniversite Kütüphanelerinde Çalışan Kütüphanecilerin Toplumsal Cinsiyet Algısı, 54. 
Tablo 9 devam

\begin{tabular}{|c|c|c|c|c|c|c|c|c|}
\hline & Hizmet Yılı & $\mathbf{n}$ & $x$ & $\mathbf{S}$ & Sd & $\mathbf{F}$ & $\mathbf{p}$ & $\begin{array}{c}\text { Grp. Ar. } \\
\text { Fark.* }\end{array}$ \\
\hline \multirow{6}{*}{ 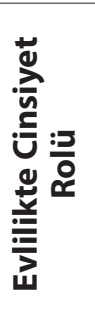 } & 1-5 Yll & 43 & 32,48 & 3,18 & \multirow{6}{*}{$5 / 255$} & \multirow{6}{*}{7,57} & \multirow{6}{*}{0,00} & $a b$ \\
\hline & 6-10 YIl & 66 & 32,72 & 3,33 & & & & $a b$ \\
\hline & 11-15 Yıl & 52 & 33,71 & 3,24 & & & & $a$ \\
\hline & 16-20 YII & 24 & 31,2 & 4,02 & & & & $\mathrm{bc}$ \\
\hline & 21-25 Yıl & 21 & 31,23 & 2,8 & & & & bc \\
\hline & 26 Yıl ve üstü & 50 & 30,08 & 3,08 & & & & C \\
\hline \multirow{6}{*}{ 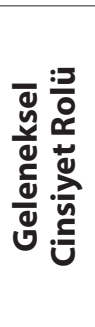 } & $1-5 \mathrm{YIl}$ & 43 & 23,46 & 4,54 & \multirow{6}{*}{$5 / 255$} & \multirow{6}{*}{3,48} & \multirow{6}{*}{0,00} & a \\
\hline & 6-10 YII & 66 & 22,3 & 4,88 & & & & $a b$ \\
\hline & 11-15 Yıl & 52 & 23,61 & 5,84 & & & & $\mathrm{a}$ \\
\hline & 16-20 YII & 24 & 20,75 & 4,84 & & & & $a b$ \\
\hline & 21-25 YII & 21 & 19,52 & 4,3 & & & & $\mathrm{~b}$ \\
\hline & 26 Yıl ve üstü & 50 & 21,18 & 4,63 & & & & $a b$ \\
\hline \multirow{6}{*}{ 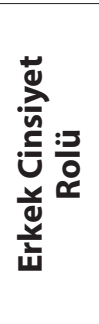 } & 1-5 YIl & 43 & 22,34 & 3,37 & \multirow{6}{*}{$5 / 255$} & \multirow{6}{*}{6,63} & \multirow{6}{*}{0,00} & $a b$ \\
\hline & 6-10 YII & 66 & 22,62 & 3,01 & & & & a \\
\hline & 11-15 YII & 52 & 23 & 3 & & & & a \\
\hline & 16-20 YII & 24 & 22,08 & 3,9 & & & & $a b$ \\
\hline & $21-25 Y_{I I}$ & 21 & 19,47 & 2,31 & & & & c \\
\hline & 26 Yıl ve üstü & 50 & 20,28 & 3,88 & & & & bc \\
\hline \multirow{6}{*}{ 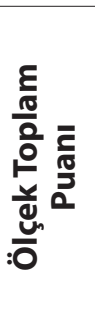 } & 1-5 YII & 43 & 134,48 & 10,85 & \multirow{6}{*}{$5 / 255$} & \multirow{6}{*}{13,75} & \multirow{6}{*}{0,00} & $a b$ \\
\hline & 6-10 Yıl & 66 & 132,45 & 12,23 & & & & $a b$ \\
\hline & 11-15 YII & 52 & 135,46 & 10,94 & & & & $a$ \\
\hline & 16-20 YII & 24 & 127,62 & 13,62 & & & & $\mathrm{bc}$ \\
\hline & 21-25 YII & 21 & 119,52 & 7,58 & & & & $\mathrm{~d}$ \\
\hline & 26 Yıl ve üstü & 50 & 122,36 & 8.43 & & & & $\mathrm{~cd}$ \\
\hline
\end{tabular}

Yukarıda Tablo 9'da din görevlilerinin görevde geçirdiği hizmet yılına göre TCRTÖ ve alt boyutlarına ait tutum puanlarının istatistiksel analizi verilmiştir. Ölçek toplam puan verileri açısından, görevdeki hizmet yılına göre din görevlilerinin toplumsal cinsiyet rollerine ilişkin tutumları arasında yüksek derecede anlamlı bir farklılık bulunmuştur ( $F=13,75 p=0,00, p<0,01)$. Hizmet yılı 11-15 yıl olan $(135,46)$ din görevlileri ile hizmet yılı 21-25 yıl olan $(119,52)$ din görevlileri arasında farklılaşma tespit edilmiştir. 
TCRTÖ tüm alt boyutlarında da görevdeki hizmet yılına göre din görevlilerinin toplumsal cinsiyet rollerine ilişkin tutumları arasında yüksek derecede anlamlı bir farklılık $(p=0,00, p<0,01)$ tespit edilmiştir. Farkın hangi gruplar arasında olduğunu belirlemek için yapılan analizlerde, eşitlikçi cinsiyet rolü alt boyutunda 1-5 yıl $(32,04), 6-10$ yıl $(31,5)$ ve 11-15 yıl $(32,61)$ hizmeti olanlar ile $21-25$ yıl $(25,9)$ hizmeti olanlar arasında; kadın cinsiyet rolü alt boyutunda 11-15 yıl $(32,71)$ hizmeti olanlarla 26 ve üstü yıl $(30,08)$ hizmeti olanlar arasında; evlilikte cinsiyet rolü alt boyutunda da 11-15 yıl $(32,71)$ hizmeti olanlar ile 26 yıl ve üstü $(30,08)$ hizmeti olanlar arasında anlamlı farklılık tespit edilmiştir. Geleneksel cinsiyet rolü alt boyutunda 1-5 yıl $(23,46), 11-15$ yıl $(23,61)$ hizmeti olanlar ile $21-25$ yıl $(19,52)$ hizmeti olanlar arasında; erkek cinsiyet rolü alt boyutunda ise 6-10 yıl $(22,62), 11$ 15 yıl $(23)$ hizmeti olanlar ile 21-25 yıl $(19,47)$ hizmeti olanların tutum puanlarında anlamlı farklılık olduğu görülmüştür.

Yaş arttıkça görevde hizmet yılı arttığı için bu bulgular yaş ve toplumsal cinsiyet rolleri arasındaki ilişkiyi gösteren bulgularla da örtüşmektedir (bk. Tablo 4). Hizmet yılı arttıkça din görevlilerinin toplumsal cinsiyet rolleri açısından daha geleneksel tutumlar içinde olduğu söylenebilir.

Alan araştırmaları incelendiğinde bu verilerle benzerlik göstermeyen sonuçların da tespit edildiği görülmektedir. Bekleviç çalışmasında hizmet yılının toplumsal cinsiyet rollerine ilişkin tutumlar arasında anlamlı bir fark oluşturmadığını, ${ }^{91}$ Özden ve arkadaşları ise hizmet yılı 11 yıldan fazla olanların daha az hizmet süresi olanlara göre daha eşitlikçi bir tutum gösterdikleri sonucuna ulaşmıştır. ${ }^{92}$

\section{Sonuç}

Din toplumun sosyo-kültürel yapısı içindeki önemli unsurlardan biridir. Bireye ve topluma zihniyet kalıpları sunarak neyi nasıl düşüneceğine dair yol gösterir. Her din belli bir toplumsal ve kültürel ortamda doğar ve gelişir. Bu durum din ve toplum arasında güçlü bir etkileşim oluşturur. Bizim toplumumuz da dahil olmak üzere pek çok toplumda din ve kültür o kadar kaynaşmıştır ki dinî ve kültürel olanı birbirinden net bir şekilde ayırmak kolay değildir. Bundan dolayı toplumun kültürel yapısından kaynaklanan kimi ataerkil tutumlar, dinin parçası olarak algılanmakta, bu da dinin toplumsal cinsiyet oluşumuna katkı sağlayan unsurlardan biri olduğunu düşündürmektedir.

Din ve toplumsal cinsiyet ilişkisini ele alan bu çalışmamız din görevlilerinin toplumsal cinsiyet rollerine ilişkin tutumlarını ortaya koyarak bu ilişsiyi belli bir boyutta açıklamaya çalışmıştır. Çalışmada katılımcıların sosyo-demografik özelliklerine göre toplumsal cinsiyet rollerine ilişkin tutumlarında bir farklılaşma

91 Bekleviç, Bir Üniversite Hastanesi Araştırma Görevlilerinin Toplumsal Cinsiyet Rolleri Tutum Ölçeği ve Çalışma Yaşamında Toplumsal Cinsiyet Rolleri Algısının Değerlendirilmesi, 34.

92 Özden - Gölbaşı, “Sağlık Çalışanlarının Toplumsal Cinsiyet Rollerine Illişkin Tutumlarının Belirlenmesi”, 100. 
olup olmadığı incelenmiştir. Buna göre saha araştırmalarında elde edilen bulgular şöyledir:

i) Dingörevlilerinin TCRTÖ’nün alt boyutlarından aldıkları puan ortalamaları karşılaştıııldığında en düşük puan ortalamasının 'geleneksel cinsiyet rolü' alt boyutuna, en yüksek puan ortalamasının ise 'evlilikte cinsiyet rolü' ve 'kadın cinsiyet rolü' alt boyutuna ait olduğu görülmüştür. Bu durum din görevlilerinin toplumsal cinsiyet tutumlarının eşitlikçi olmasına rağmen bazı tutumlarda geleneksel eğilimler gösterdiği şeklinde yorumlanabilir.

ii) Kadın din görevlileri, erkek din görevlilerine göre toplumsal cinsiyet rollerine ilişkin daha eşitlikçi bir tutum içindedirler. Bunun nedeni toplumsal cinsiyet eşitsizliğinde dezavantajlı grubun genellikle kadınlar olmasıdır. Toplumsal cinsiyet rollerine ilişkin tutumlarda eşitlikçi olmak, bir yandan görüntünün kadınlar lehine dönmesi diğer yandan erkeklerin elinde tuttuğu güç ve otoriteyi kadınla paylaşmak anlamına geldiğinden erkeklerin toplumsal cinsiyet rollerine ilişkin tutumlarda kadınlardan daha geleneksel tutum içinde olmaları beklenen bir durumdur.

iii) 51 yaş ve üstü gruptaki din görevlileri, diğer yaş grubundakilere göre toplumsal cinsiyet rollerine ilişkin daha geleneksel bir tutum göstermektedir. Din görevlilerinin yaşları ile toplumsal cinsiyet rollerine ilişkin tutumları arasında negatif bir ilişki vardır. Yaş ilerledikçe daha geleneksel bir tutum sergilenmektedir. Bununla birlikte genç neslin daha eşitlikçi tutumda olması çağın şartlarına daha rahat uyum sağladıklarını da göstermektedir.

iv) Lisans ve lisansüstü mezunu olan din görevlileri, lise ve ön lisans mezunu olan din görevlilerine göre toplumsal cinsiyet rollerine ilişkin daha eşitlikçi bir tutum içindedirler. Din görevlilerinin öğrenim seviyesi ile toplumsal cinsiyet rolleri arasında pozitif bir ilişki vardır. Eğitim seviyesi arttıkça daha eşitlikçi bir tutum sergilenmektedirler. Bu bulgu eğitim-öğretimin toplumsal cinsiyet rollerine ilişkin eşitlikçi tutumların yaygınlaştırılmasında ne kadar önemli olduğunun da göstergesidir.

v) Din görevlileri, eşlerinin eğitim seviyesi yükseldikçe toplumsal cinsiyet rollerine ilişkin daha eşitlikçi bir tutum göstermektedir. Bu sonuca göre eşin öğrenim seviyesi de bireylerin hayata bakış açılarını etkileyen faktörlerden biridir.

vi) Kur'an kursu öğreticisi olarak görev yapan din görevlileri imam-hatip ve müezzin kayyımlara göre toplumsal cinsiyet rollerine ilişkin daha eşitlikçi bir tutum içindedirler. Din görevlileri içinde imam-hatip ve müezzin kayyımların tamamının erkek; Kur'an kursu öğreticilerinin de büyük çoğunluğunun kadın olduğu düşünüldüğünde aslında burada görev türünden 
ziyade cinsiyetin toplumsal cinsiyet rollerine ilişkin tutumları etkilemede daha belirleyici olduğu düşünülmektedir.

vii) IIl merkezinde görev yapan din görevlileri köyde görev yapanlara göre toplumsal cinsiyet rollerine ilişkin daha eşitlikçi bir tutum göstermektedir. Din görevlilerinin yaşadığı yer, onların toplumsal cinsiyet rolleri karşısındaki tutumlarını etkilemektedir. Şehirde yaşayanlar köyde yaşayanlara göre daha eşitlikçi bir tutum göstermektedirler. Şehirde yaşamanın sunduğu imkânlar, şehirde çekirdek aile modelinin yaygınlığı, şehirde yaşayanlarda kadının ev dışı ücretli bir işte daha çok çalışıyor olması gibi farklılıklar yaşanan ortamın toplumsal cinsiyet rollerine ilişkin algıyı etkilediği söylenebilir. Bununla birlikte Kur'an kursu öğreticilerinin büyük çoğunluğunun kadın olması ve şehir merkezinde görev yapmasının, sonucu bu şekilde etkilemiş olabileceği de göz önünde bulundurulmalıdır.

viii) Din görevlilerinin görevde hizmet yılları arttıkça (özellikle hizmet yılı 15 yılı aşanlarda) toplumsal cinsiyet rollerine ilişkin tutum puanlarının azaldığı görülmektedir. Görevde hizmet yılı arttıkça yaş da arttığı için bu bulgular yaş ve toplumsal cinsiyet rolleri arasındaki ilişkiyi gösteren bulgularla örtüşmektedir. Hizmet yılı arttıkça din görevlilerinin daha geleneksel tutumlar içinde olduğu görülmektedir.

Sonuç olarak, Çorum II Müftülüğüne bağlı merkez ve merkez köylerde görev yapan din görevlilerinin yaş, cinsiyet, eğitim durumu, eşin eğitim durumu, görev türü, görev yeri ve hizmet yılı gibi değişkenlere göre toplumsal cinsiyet rollerine ilişkin tutumlarında farklılıklar tespit edilmiştir. 


\section{Kaynakça}

Akdemir, Salih. “Tarih Boyunca ve Kur'an-ı Kerim'de Kadın”. İslamî Araştırmalar 10/4 (1997), 249-258.

Aksel, Hesna Serra. "Feminist Perspektiften Yahudilik: Bir Yeniden İnşa Girişimi”. Hitit Ilahiyat Dergisi 20/1 (2021), 139-166.

Albayrak, H. Şule. "Kadın Olmak \& İslam, Gelenek, Modernlik ve Ötesi". İstanbul: İz Yayıncılık, 2019.

Amman, Mehmet Tayfun. "Toplumsal Boyutlarıyla Cinsiyet- Sosyal, Bilimsel Yaklaşımlar-". Din ve Toplumsal Boyutlarıyla Cinsiyet Tartışmalı Ilmi Ihtisas Toplantı, (2011), 13-55.

Aynur, Hatice Şahin. "İslamî Feminizm ve Feminist Kur'ân Okumaları Üzerine Genel Bir Değerlendirme". Dinbilimleri Akademik Araştırma Dergisi 13/1 (2013), 89-122.

Bekleviç, Arzum Çelik. Bir Üniversite Hastanesi Araştırma Görevlilerinin Toplumsal Cinsiyet Rolleri Tutum Ölçeği ve Çalışma Yaşamında Toplumsal Cinsiyet Rolleri Algısının Değerlendirilmesi. Zonguldak: Bülent Ecevit Üniversitesi, Yüksek Lisans Tezi, 2013.

Berktay, Fatmagül. Tarihin Cinsiyeti. İstanbul: Metis Yayınları, 2018.

Berktay, Fatmagül. Tek Tanrıı Dinler Karşısında Kadın. İstanbul: Metis Yayınları, 3. Basım, 2009.

Bhasin, Kamla. Toplumsal Cinsiyet: Bize Yüklenen Roller. çev. Kader Ay. İstanbul: Kadav Yayınları, 2003.

Burr, Vivien. Gender and Social Psychology. London and New York: Routledge, 1998.

Butler, Judith. Cinsiyet Belası. çev. Başak Ertür. Metis Yayınları, 4. Basım, 2014.

Connell, Robert William. Toplumsal Cinsiyet ve Iktidar. çev. Cem Soydemir. İstanbul: Ayrıntı Yayınları, 1998.

Çaviş, Abdulaziz. Anglikan Kilisesine Cevap. çev. Mehmet Akif Ersoy. Ankara: Diyanet İşleri Başkanlığı Yayınları, 1974.

Çoştu Ceyhan, Feyza. "II. Meşrutiyet Aydınlarından Baha Tevfik ve Kadın", Uluslararası Sosyal Araştırmalar Dergisi 13/75 (2020), 435-443.

Deniz Kandiyoti. "Türkiye'de Toplumsal Cinsiyet ve Kadın Çalışmaları: Gelecek İçin Geçmişe Bakış". Birkaç Arpa Boyu, 21 Yüzyıl'a Girerken Türkiye'de Feminist Çalışmalar: Prof. Dr. Nermin Abadan Unat'a Armağan. ed. Serpil Sancar. 1/41-61. İstanbul: Koç Üniversitesi Yayınları, 2011.

Dökmen, Zehra Yaşın. Toplumsal Cinsiyet Sosyal Psikolojik Açıklamalar. İstanbul: Remzi Kitabevi, 2019.

Evrim, Selmin. Şahsiyet Alanında Rol Sorununa Giriş. İstanbul: İstanbul Üniversitesi Edebiyat Fakültesi Yayınları, 1972.

Fisher, Mary Pat. Women in Religion. New York: Pearson \& Longman, 2007.

Giddens, Anthony. Sosyoloji. çev. İsmail Yılmaz. İstanbul: Kırmızı Yayınları, 2012.

Göle, Nilüfer. Modern Mahrem. İstanbul: Metis Yayınları, 1991.

Gürhan, Nazife. "Toplumsal Cinsiyet ve Din”. e-Şarkiyat IIImi Araştırmalar Dergisi 4 (Kasım 2010), 58-80. 
Johnstone, Ronald L. Religion on Society: Sociology of Religion. Prentice Hall, 2006.

Kenevir, Fatma - Kurt, Şeyda Koçak. "Türkiye'de Toplumsal Cinsiyet ve Din Temalı Tez Çalışmaları Üzerine Bir Değerlendirme". Dini Araştırmalar 19/49 (2016), 347-383.

Keskin, Fatma. Ilahiyat Fakültesi Öğrencilerinin Toplumsal Cinsiyet Rollerine Illişkin Tutumları. Konya: Necmettin Erbakan Üniversitesi, Yüksek Lisans Tezi, 2019.

Kırbaşoğlu, Hayri. "Kadın Konusunda Kur'ân'a Yöneltilen Başlıca Eleştiriler". İslamî Araştırmalar 10/4 (1997), 259-270.

Komisyon. Örnekleriyle Türkçe Sözlük. İstanbul: MEB, 2000.

Kurşun, Emel. Samsun Halk Sağlığı Müdürlüğü'nde Çalışan Personelin Toplumsal Cinsiyet Rol Tutumlarının Belirlenmesi. Samsun: Ondokuz Mayıs Üniversitesi, Yüksek Lisans Tezi, 2016.

Kuzgun, Yıldız - Sevim, Seher A. "Kadınların Çalışmasına Karşı Tutum ve Dini Yönelim Arasındaki Illişki". Ankara Üniversitesi Eğitim Bilimleri Fakültesi Dergisi 37/1 (2004), 14-27.

Marshall, Gordon. Sosyoloji sözlüğü çev. Osman Akınhay ve Derya Kömürcü. Ankara: Bilim ve Sanat Yayınları, 1999.

Mernissi, Fatıma. Peçenin Ötesi. çev. Mine Küpçü. İstanbul: Yayınevi Yayıncılık, 1995.

Okutan, Birsen Banu. Erillik ve Din: İslamcı Habitus Sorgulanıyor. İstanbul: Rağbet Yayınları, 2017.

Okutan, Birsen Banu. "Akışkan Modern Zamanlarda Kadın ve Din: Yaşama Üslubundan Hayat Tarzına Habitusun Değişimi". Dini Araştırmalar 19/49 (2016), 229-253.

Okutan, Birsen Banu. "Din ve Toplumsal Cinsiyet Çalışmalarının Teorik ve Metodolojik İmkânı: Literatürel Bir Değerlendirme". Toplum Bilimleri Dergisi 7/13 (2013), 7-24.

Önder, Ömer R. vd. "Sağlık Kurumları Yöneticiliği Bölümü Öğrencilerinin Toplumsal Cinsiyet Rollerine İlişkin Tutumları". Ankara Sağlık Bilimleri Dergisi 2 (2013), 55-78.

Özden, Serpil - Gölbaşı, Zehra. "Sağlık Çalışanlarının Toplumsal Cinsiyet Rollerine İlişkin Tutumlarının Belirlenmesi". KOU Sağlık Bilimleri Dergisi 4/3 (2018), 95-100.

Öztürk, Emine. Türkiye'de Aile İçi Şiddet Kadın Sığınma Evleri ve Din. İstanbul: Marmara Üniversitesi, Doktora Tezi, 2008.

Saygılıgil, Feryal. Toplumsal Cinsiyet Tartışmaları. İstanbul: İstanbul Üniversitesi Açık ve Uzaktan Eğitim Fakültesi, 2010.

Scott, Joan W. "Toplumsal Cinsiyet: Faydalı Bir Tarihsel Analiz Kategorisi”. çev. Derya Demirler - Fahriye Dinçer. Kültür ve Siyasette Feminist Yaklaşımlar 12 (2010), 112-138.

Şeriati, Ali. Kadın (Fatıma Fatımadır). çev. Esra Özlük. Ankara: Fecr Yayınları, 2. Basım, 2011.

Tam, Gülşah. Diyanet Çalışanlarının Toplumsal Cinsiyet Rollerine Ilişkin Tutumları. Mersin: Mersin Üniversitesi, Yüksek Lisans Tezi, 2020.

Tekin, Mustafa. Türkiye 'de Aydın Kadınlara Göre Din ve Kadın. Konya: Selçuk Üniversitesi, Doktora Tezi, 2003.

Terzioğlu, Hülya. "Toplumsal Cinsiyet Anlayışına Katkısı Bağlamında Dini Söylemin Etkisi”. Kelam Araştırmaları Dergisi 14/2 (2016), 541-558. 
Toker, İhsan. "Dinler Ataerkil Yapılar Mıdır? Bir Çifte İmkanlılık Konusu Olarak Din ve Kadın". Eski Yeni 12 (2009), 15-21.

Toker, İhsan. "Eşitlik ve Adalet Kavramları Çerçevesinde Müslüman Kadınlarda Toplumsal Cinsiyet Örüntüleri". Ankara Üniversitesi Sosyal Bilimler Enstitüsü Dergisi 1/1 (2009), 142-165.

Toker, Ihssan. "Toplumsal Cinsiyet ve Din”. Din Sosyolojisi. ed. Niyazi Akyüz-ihsan Çapcıoğlu. 607-623. Ankara: Grafiker Yayınları, 5. Basım, 2018.

Toker, İhsan. Bir Yapılaşma Illişkisi Olarak Kadınlar ve Din -Başkent Kadın Platformu Örnek Olayı-. Ankara: Ankara Üniversitesi, Doktora Tezi, 2005.

Tuksal, Hidayet Şefkatli. Kadın Karşıtı Söylemin İslam Geleneğindeki İdüşümleri. Ankara: Kitabiyat, 2000.

Tunç, Harun. Toplumsal Değişim Sürecinde Din ve Toplumsal Cinsiyet. Kahramanmaraş: Kahramanmaraş Sütçü İmam Üniversitesi, Yüksek Lisans Tezi, 2013.

Uysal, Veysel. "Günümüz Türk Toplumunda Dinsellik ve Kadın/Erkek Aleyhtarı Tutumlar". Marmara Üniversitesi Illahiyat Fakültesi Dergisi 20 (2001), 81-114.

Ünalan, Eda. Türkiye'deki Üniversite Kütüphanelerinde Çalışan Kütüphanecilerin Toplumsal Cinsiyet Algısı. Ankara: Ankara Üniversitesi, Yüksek Lisans Tezi, 2020.

Ünalan Turan, Sümeyra , Bilgin, Vejdi. "Toplumsal Cinsiyet Ekseninde Din ve Aile İçi Roller". Uludağ Üniversitesi İlahiyat Fakültesi Dergisi 29/2 (Aralık 2020), 459-493 .

Vedud Muhsin, Amine. Kur'an ve Kadın. İstanbul: İz Yayıncilık, 1997.

World Health Organisation (WHO). "Gender and Health". Tecnical Paper.

Yapıcı, Asım. "Yeni Bir Dindarlık Ölçeği ve Üniversiteli Gençlerin Dinin Etkisini Hissetme Düzeyi: Çukurova Üniversitesi Örneği". Çukurova Üniversitesi Illahiyat Fakültesi Dergisi 6/1 (2006), 65-115.

Yapıcı, Asım. Toplumsal Cinsiyet Din ve Kadın. İstanbul: Çamlıca Yayınları, 2016.

Zengin, Ayşe Çağrıcı. Dindarlık ve Toplumsal Cinsiyet Ayrımcılığı. Sivas: Cumhuriyet Üniversitesi, Doktora Tezi, 2019.

Zeyneloğlu, Simge. Ankara'da Hemşirelik Öğrenimi Gören Üniversite Öğrencilerinin Toplumsal Cinsiyet Rollerine Illişkin Tutumları. Ankara: Hacettepe Üniversitesi, Doktora Tezi, 2008. 
